\title{
A constitucionalização da Defensoria Pública: disputas por espaço no sistema de justiça ${ }^{1}$
}

Thiago de Miranda Queiroz Moreira

\section{Introdução}

A constitucionalização da Defensoria Pública foi uma das inovações introduzidas pela Assembleia Nacional Constituinte (ANC) de 1987-1988 no sistema de justiça brasileiro. A Constituição Federal, em seu texto original, definiu que a Defensoria é "instituição essencial à função jurisdicional do Estado" e deve ser composta por servidores públicos concursados responsáveis por prestar orientação e defesa jurídicas aos necessitados, ou seja, a toda e qualquer pessoa que comprovar insuficiência de recursos para arcar com os custos da advocacia privada². Desse modo, cabe à Defensoria oferecer "assistência jurídica integral e gratuita" à população carente, nos termos do artigo 50, inciso LXXIV, da Constituição. Da redação constitucional, depreende-se ainda que a União e todos os estados deveriam construir as suas próprias Defensorias ${ }^{3}$. Portanto, a ANC adotou um modelo estatal de assistência jurídica, no qual o serviço é prestado por advogados concursados, com carreira própria e especializados nas questões jurídicas da população carente (Cunha, 2001; Rocha, 2009).

Por tratar-se de uma instituição jurídica cujos serviços são primordialmente destinados às pessoas necessitadas, estudos relacionados à ciência política costumam analisar o papel da Defensoria Pública na promoção do acesso à justiça, geralmente sob a ótica de pressupostos normativos referentes à capacidade da instituição de promover a justiça social e democratizar o sistema de justiça (Sadek, 2005, 2008; Zaffalon, 2010; Santos, 2011; Haddad, 2011; Madeira, 2012; Marona, 2013; Cunha e Feferbaum, 2014). Em linhas gerais, esses estudos fazem um balanço entre o potencial da Defensoria para promoção da cidadania e os diferentes aspectos que limitam sua capacidade de ação. 0 enfoque deste artigo é diferente. Parte de uma pesquisa mais ampla que investiga o processo de institucionalização da Defensoria Pública e compara a criação da instituição nos estados, focando um momento histórico crucial para compreender a formação e a evolução da Defensoria no Brasil: a Constituinte de 1987-1988.

\footnotetext{
1 Este artigo é parte da pesquisa que resultou na minha dissertação de mestrado, defendida em 2016. Agradeço aos comentários de Wagner Pralon Mancuso, Rogério Arantes e Adrian Gurza Lavalle a versões anteriores deste artigo. Também sou grato aos comentários precisos do Glauco Peres da Silva e de dois pareceristas anônimos da revista.

2 Artigo 134 da Constituição Federal.

3 Parágrafo único do artigo 134 da Constituição, convertido em $\S 1^{\circ}$ pela EC 45/2004. A lei complementar em questão é a LC 80/1994, que sofreu alterações da LC 132/2009.
} 
O objetivo é entender como a Defensoria, um dentre outros arranjos institucionais de assistência judiciária então existentes, foi inserida na Constituição como o modelo escolhido para uniformizar o serviço de acesso à justiça às pessoas carentes no Brasil. Para tanto, este artigo recorreu a uma análise meticulosa das Atas dos Debates da $\mathrm{ANC}^{4}$ e das emendas relacionadas com a Defensoria apresentadas aos anteprojetos e projetos de Constituição ${ }^{5}$. Nos documentos de todas as etapas da Constituinte, a expressão "Defensoria" foi pesquisada, para selecionar os trechos em que esse tema era debatido e, assim, compreender, a partir da leitura das atas, emendas propostas e anteprojetos, quais questões estavam em disputa naquele momento. Desse modo, a análise textual dos documentos permite reconstruir esse capítulo importante da história da Defensoria Pública, identificando os atores e interesses em disputa durante a constitucionalização de tal arranjo de assistência jurídica. Os trechos dos documentos citados aqui constituem material empírico que registra, de maneira clara, os conflitos envolvidos na inclusão da Defensoria no texto constitucional.

Veremos neste artigo que a Defensoria surgiu como uma forma específica de assistência judiciária que se estabeleceu como modelo vinculante para todo o país graças, sobretudo, ao esforço de seus integrantes. A atuação política de defensores públicos e de outros servidores ligados à assistência judiciária, exercida frequentemente por meio de associações representativas da categoria, foi fundamental para constitucionalizar a Defensoria Pública. Todavia, a pretensão dos defensores deparou-se com a resistência de outras carreiras jurídicas, que se opuseram durante a ANC à previsão constitucional de uma instituição específica para a prestação de assistência jurídica.

O pressuposto analítico deste artigo assume que regimes de política pública, constituídos em arranjos institucionais distintos, geram padrões diferentes de interação entre os grupos de interesse, influenciando não apenas as suas estratégias, mas também os seus objetivos. A assistência jurídica é a política pública destinada a garantir o acesso das pessoas carentes aos serviços de prestação jurisdicional do Estado. A análise dos debates da ANC empreendida aqui identifica padrões de conflito em torno da construção da Defensoria Pública, demonstrando que a existência de regimes diferentes de assistência judiciária, estabelecidos na época em certos estados, fixaram interesses contrários ao projeto de institucionalização da Defensoria.

Entender esses interesses em conflito, bem como que a força motriz da inclusão constitucional da Defensoria Pública residiu no ativismo dos próprios defensores, representa uma contribuição importante à literatura sobre a instituição, que tende a ressaltar o seu potencial para a transformação social do Brasil por meio da judicialização

\footnotetext{
4 Todas as Atas dos Debates da ANC estão disponíveis no sítio eletrônico do Senado Federal em: <http://www.senado.gov.br/publicacoes/anais/asp/CT_Abertura.asp>.

${ }^{5}$ Durante a ANC, houve uma série de anteprojetos e projetos sucessivos. Os textos sobre a Defensoria nos anteprojetos e projetos estão reproduzidos no anexo deste artigo. As emendas que foram apresentadas na ANC podem ser consultadas no sítio eletrônico da Câmara dos Deputados em:

<http://www2.camara.leg.br/atividade-legislativa/legislacao/Constituicoes_Brasileiras/constituicaocidada/o-processo-constituinte $>$.
} 
da política (Zaffalon, 2010; Marona, 2013), mas atualmente costuma constatar que esse potencial não se concretizou. Sadek, por exemplo, argumentou que a Defensoria "tem potencial para produzir reflexos imediatos na realidade, reduzindo o grau de exclusão social" que assola o país (2005, p. 284), ao passo que Cunha e Feferbaum (2014) avaliaram recentemente algumas limitações práticas para que a instituição possa exercer esse papel de agente transformador da realidade. Os debates da ANC revelam que a Defensoria Pública encontrou grande resistência para se instalar no sistema de justiça, e que, em boa medida, a atuação dos defensores públicos foi essencial para incluir a Defensoria na Constituição. As dificuldades para a consolidação da instituição e os interesses corporativos dos seus membros conduzem, frequentemente, a uma realidade institucional distinta daquela inicialmente vislumbrada pela literatura.

Para retratar esse capítulo da história da Defensoria Pública, este artigo divide-se em quatro seções. A primeira, "A dispersão de arranjos institucionais de assistência judiciária", descreve a evolução da assistência jurídica no Brasil, apresentando sinteticamente os diferentes arranjos para desempenhar essa política que existiam antes de 1988. Essa seção encerra-se com a exposição do pressuposto analítico deste artigo, ancorado na abordagem do institucionalismo histórico, e permite traçar um panorama do que estava em jogo quando se discutiu a previsão constitucional da Defensoria. A segunda seção, "A origem da Defensoria Pública e o projeto institucional dos defensores", resume o surgimento e a expansão da Defensoria antes da Constituição de 1988. Na terceira parte, "Defensoria Pública e acesso à justiça nos debates da Constituinte", os debates da ANC sobre a Defensoria são analisados, revelando os choques corporativos que começavam a eclodir no sistema de justiça com a determinação constitucional de criar a Defensoria Pública em todo o país. Conforme apresentamos adiante, o artigo 134 do texto original da Constituição é o resultado desses conflitos. A última seção, "Resultado constituinte: projeto de consolidação da Defensoria permaneceu aberto", sintetiza os embates e demonstra que o resultado do processo constituinte postergou a proposta de consolidação institucional dos defensores públicos para além do momento de elaboração constitucional. Os debates da ANC são uma fonte importante de informação para entender o processo de institucionalização da Defensoria nas décadas seguintes (Moreira, 2016) e expõem o ativismo político de atores estatais, ou seja, que grupos profissionais oriundos da máquina pública participaram da ANC visando fortalecer suas instituições e carreiras.

\section{A dispersão de arranjos institucionais de assistência judiciária}

Embora a previsão legal da assistência judiciária ${ }^{6}$ no Brasil não seja recente, foi somente com a Constituição de 1988 que a existência de uma instituição pública

\footnotetext{
6 "Assistência judiciária" e "assistência jurídica" são expressões muitas vezes utilizadas indistintamente. Contudo, a segunda tornou-se recorrente a partir da década de 1980, substituindo a primeira, que é considerada restritiva por transmitir a ideia de que a assistência se limita à defesa perante o Judiciário, sem
} 
especificamente destinada a prestar serviços de defesa e orientação jurídica às camadas mais pobres da população se tornou legalmente obrigatória ao poder público.

Durante a República Oligárquica (1889-1930), a assistência judiciária, entendida rudimentarmente como a defesa na esfera criminal de pessoas pobres, era atribuída aos "curadores geraes", que pertenciam aos quadros do Ministério Público7. Após a Revolução de 1930, a Constituição de 1934 chegou a definir que a União e os estados concederiam assistência judiciária para pessoas necessitadas, determinando inclusive a criação de "órgãos especiais" para esse serviço ${ }^{8}$. Contudo, diante da curta duração dessa Constituição, a criação de uma instituição com essa função não se concretizou na época. As Constituições de 1946 e de 1967-1969 também trataram a assistência judiciária como uma concessão do poder público, a qual deveria ser atendida "na forma da lei" ${ }^{9}$. Tal lei foi promulgada em 1950 sob o n 1.060 e está em vigor até os dias de hoje. Atualmente, sua principal utilidade é definir critérios e procedimentos para que o Judiciário possa deferir aos jurisdicionados carentes a isenção de taxas, custas e honorários. Quanto ao serviço de defesa jurídica das pessoas necessitadas, tal lei não previu a existência de um órgão público destinado a esse fim (Cunha, 2001, p. 158) e acabou definindo como solução a nomeação de advogados particulares, ou até mesmo de estudantes de direito ${ }^{10}$, onde não houvesse serviço de assistência judiciária organizado e mantido pelo Estado.

Não obstante, com base nessa legislação e seguindo uma tendência geral nos países ocidentais de expandir o acesso à justiça (Cappelletti e Garth, 1988), os estados brasileiros adotaram suas próprias soluções para tentar garantir condições mínimas de assistência judiciária. Tais soluções evoluíram em três direções possíveis: instituir um órgão público específico para desempenhar a assistência jurídica, criando em alguns casos as primeiras Defensorias; atribuir essa função a alguma instituição já existente, em regra a Procuradoria-Geral do Estado (PGE) ${ }^{11}$; ou remunerar com recursos públicos os advogados particulares que atendiam à demanda da população carente por serviços jurídicos. Essas iniciativas podem ser classificadas de acordo com os modelos apresentados pelo clássico estudo sobre acesso à justiça de Cappelletti e Garth (1988). Os autores definem os modelos de assistência judiciária aos pobres com base nos profissionais responsáveis por essa função, destacando se são advogados particulares ou servidores públicos. Assim, o primeiro modelo que apresentam é o "sistema judicare", no qual advogados particulares são pagos pelo Estado por prestarem serviços jurídicos às pessoas necessitadas. 0 segundo, que os autores chamam de "advogados remunerados pelos cofres públicos" (Cappelletti e Garth, 1988, p. 39), é composto por servidores públicos especializados em

incluir atividades de orientação sobre direitos e atuação em vias extrajudiciais. Para definição dos conceitos, ver Marcacini (1996).

${ }^{7}$ Artigo 175 do Decreto no 1.030 de novembro de 1890.

${ }^{8}$ A assistência judiciária estava prevista no artigo 113, item 32, da Constituição de 1934.

${ }^{9}$ Artigo 141, §35, da Constituição de 1946 e artigo 150, §32, da Constituição do Regime Militar.

10 Artigo 50, $\S 2^{\circ}$ e $\S 3^{\circ}$, e artigo 18 da Lei 1.060/1950.

11 PGE é a instituição responsável por defender os interesses jurídicos do próprio Estado. 
direitos relativos às pessoas pobres. Por fim, há o modelo misto, que oferece a escolha entre servidores públicos e advogados particulares.

Portanto, até 1988, vigia no Brasil a dispersão de arranjos de assistência judiciária, com cada estado adotando formas variadas de um dos três modelos descritos por Cappelletti e Garth. A previsão constitucional da Defensoria Pública buscou concentrar a política de acesso à justiça para pessoas carentes em um modelo de "advogados servidores públicos" uniforme para todo o país. Todavia, em torno de outros arranjos de assistência judiciária instituídos em muitos estados, certos atores articularam seus interesses com a intenção de preservar suas funções e, consequentemente, evitar o surgimento da Defensoria. Em outras palavras, a implementação desse modelo constitucional de assistência judiciária a partir de 1988 não ocorreu em terreno vazio. Ao contrário, teve que disputar o espaço já ocupado por outros atores do sistema de justiça, incluindo advogados particulares, que, em alguns estados, prestavam serviços jurídicos aos necessitados e eram remunerados pelos cofres públicos, e outras categorias de servidores públicos ligados às carreiras jurídicas, sobretudo os procuradores estaduais, que, em certos locais, eram destinados a atender também à demanda jurídica das camadas populares.

Assim, na ANC não figurava no horizonte dos constituintes somente a Defensoria Pública como mecanismo de prestação da assistência judiciária. Outros atores e outras formas de realizar essa atividade já faziam parte da organização do sistema de justiça de vários estados brasileiros. Este artigo demonstra que a inclusão da Defensoria no texto constitucional é o resultado do entrechoque entre atores do sistema de justiça: defensores oriundos dos poucos estados que já possuíam essa carreira jurídica antes de 1988 pretendiam constitucionalizar o seu projeto institucional, mas tiveram que enfrentar a oposição de outras carreiras de profissionais do Direito, que exerciam a assistência judiciária em algum estado.

O argumento deste artigo adere à perspectiva teórica do institucionalismo histórico, procurando destacar que as instituições afetam a formação dos grupos de interesse, suas estratégias e os seus objetivos (Thelen e Steinmo, 1992; Pierson e Skocpol, 2002). Mais especificamente, este artigo adota a ideia de policy effects ou policy feedback, de acordo com a qual diferentes regimes de política pública engendram padrões distintos de formação de grupos de interesse, articulados por objetivos e estratégias decorrentes, em grande medida, da estrutura de política pública existente (Hacker e Pierson, 2002; Pierson, 2006). O conceito de policy effects permite observar como a organização do sistema de justiça e a existência de diferentes regimes institucionalizados de uma política pública - a assistência judiciária - influenciaram a formação de interesses e a estratégia dos atores com relação à uniformização do serviço de acesso à justiça no Brasil, proposta com base na expansão da Defensoria Pública. Seguindo esse pressuposto analítico, veremos que, quando o debate sobre a inclusão constitucional da Defensoria foi trazido à tona, outros arranjos de assistência jurídica funcionavam em estados brasileiros. Em torno 
dessas organizações, diversos atores articularam seus interesses e atuaram na ANC para defendê-los.

\section{A origem da Defensoria Pública e o projeto institucional dos defensores}

Entre os diferentes arranjos constituídos nos estados brasileiros, desenvolveu-se no Rio de Janeiro a Defensoria Pública ${ }^{12}$. Em dezembro de 1954 foram criados os primeiros seis cargos de defensores públicos estaduais, encarregados de atender juridicamente às pessoas necessitadas do estado, que até então dependiam da benevolência de advogados dativos que não recebiam por esses serviços. Em 1965, já havia cerca de cinquenta defensores no Rio de Janeiro. Nessa época, a Assistência Judiciária (AJ), como era denominada a repartição pública composta por defensores fluminenses, estava vinculada ao Ministério Público (MP) estadual, que se encontrava sob a chefia da Procuradoria-Geral de Justiça do estado ${ }^{13}$. Embora ligada ao MP, a AJ constituía um quadro próprio de profissionais, diferente do que ocorria no estado da Guanabara, onde a função de prestar serviços jurídicos aos pobres era incumbência dos membros do MP em início de carreira. No Rio de Janeiro, MP e AJ eram carreiras distintas, e não uma sucessão hierárquica dentro da mesma carreira.

A formação inicial da Assistência Judiciária ligada ao MP foi importante para os defensores fluminenses, pois fortalecia os pleitos da categoria como reivindicações associadas ao Ministério Público ${ }^{14}$. Além disso, o contato com o MP na origem da Defensoria exerceu uma influência importante, pois fez com que o modelo institucional do MP, bem como a trajetória de autonomia que essa instituição buscava na época, chegasse aos defensores públicos. O objetivo deles durante as décadas seguintes seria constituir uma Defensoria institucionalmente forte e autônoma, a exemplo do que o Ministério Público estava se tornando. Durante a Constituinte, como mostramos adiante, esse foi o projeto institucional apresentado pelos defensores para uniformizar a assistência jurídica no Brasil.

Em 1970, a transformação da AJ em órgão específico do estado, ficando ao lado do MP sob a chefia da PGE, foi um passo importante para a independência institucional pretendida pelos defensores fluminenses. Na fusão entre Guanabara e Rio de Janeiro em $1975^{15}$, essa estrutura foi mantida, em boa medida por conta da pressão exercida pelos defensores (Rocha, 2004, p. 34-46). Daí em diante, a luta para completar a institucionalização da AJ se intensificou. Os defensores pediam a autonomia administrativa e financeira do órgão, para que seus membros pudessem defender as pessoas necessitadas de forma independente, até mesmo contra o próprio Estado, e buscavam consolidar um

\footnotetext{
12 Para descrição detalhada da história da Defensoria Pública do Rio de Janeiro, ver Rocha (2004).

13 Nesse período o MP era órgão vinculado ao Executivo. Apenas com a Constituição de 1988, depois de um paulatino processo de fortalecimento desde anos anteriores, a instituição se tornou independente, tal como conhecemos hoje (Arantes, 2002).

$14 \mathrm{Na}$ época, a Associação do Ministério Público Fluminense defendia os interesses de promotores e defensores. Apenas em 1976 os defensores fundaram sua própria entidade de classe no estado.

15 Artigo 82 da Constituição do estado do Rio de Janeiro de 1975.
} 
modelo orgânico e disciplinar semelhante ao estabelecido para o Ministério Público (Rocha, 2004, p. 50-51).

No ano de 1987, os defensores fluminenses conseguiram outra conquista em direção da autonomia: a instituição passou a ser chefiada por um procurador-geral da Defensoria Pública, escolhido pelo governador a partir de lista tríplice apresentada pelos defensores. Com isso, a AJ adquiria autonomia administrativa e passava ao patamar de Secretaria de Estado, não ficando mais subordinada à PGE. Nesse período, a instituição passou a ser denominada Defensoria Pública, "para diferenciá-la das demais entidades que se propõem" à assistência jurídica (Rocha, 2004, p. 82), e consolidou a sua estrutura administrativa. Assim, a partir de seis cargos indicados pelo governador em 1954, a Defensoria Pública do Rio de Janeiro tornou-se uma instituição administrativamente autônoma em 1987, concretizando um processo bem-sucedido de institucionalização ao longo de 30 anos.

Destaca-se nesse processo a atuação política dos defensores fluminenses, principalmente por meio da associação representativa da categoria ${ }^{16}$. Pressionar a Assembleia Legislativa, fazer lobby por propostas de lei que visavam fortalecer a assistência jurídica no estado e arrancar compromissos públicos de candidatos ao governo estadual eram algumas das atividades políticas das associações dos defensores públicos do Rio de Janeiro (Rocha, 2004). Nas palavras do defensor-geral do estado, André de Castro:

A história da Defensoria Pública [fluminense] está intimamente atrelada à de sua Associação. (...) A Associação sempre esteve à frente das lutas empreendidas pela sobrevivência e reconhecimento da Defensoria Pública, não apenas em nível estadual, mas também no cenário nacional, a exemplo da intensa participação na Constituinte e na elaboração da Lei Orgânica Nacional da Defensoria Pública.

Foi através da Associação que se perseguiu e alcançou a elevação da Coordenação da Defensoria Pública ao status de Secretaria de Estado e, também, a conquista da autonomia administrativa e financeira (...) (Castro, 2004, p. xiii).

Esse ativismo constante na esfera política transformou em realidade o projeto dos defensores fluminenses, que visava consolidar a assistência jurídica do estado na forma de uma instituição autônoma. Favorecia esse projeto a ausência de outros operadores do

16 Em 1976, os defensores fluminenses formaram a sua própria entidade de classe, a Associação da Assistência Judiciária do Estado do Rio de Janeiro (AAJERJ), que, após uma cisão em 1982, deu origem à Associação dos Defensores Públicos do Estado do Rio de Janeiro (ADPERJ), existente até hoje (Rocha, 2004). 
direito interessados em disputar o atendimento jurídico à população carente do Rio de Janeiro ${ }^{17}$.

A experiência fluminense de institucionalização da Defensoria Pública influenciou atores em outros estados. Servidores públicos responsáveis pela assistência judiciária em outros locais começaram a defender um modelo semelhante ao do Rio de Janeiro, que estruturava a carreira dentro de uma instituição autônoma e especificamente designada à assistência jurídica. Esse modelo, argumentavam, geraria as condições necessárias para desempenhar com independência o atendimento jurídico pleno aos necessitados. Os defensores fluminenses também atuaram para expandir o modelo da Defensoria para todo o país. No início da década de 1980, passaram a sustentar que a assistência jurídica deveria ser, em todo o Brasil, incumbência de órgãos públicos especializados em tal função, atribuindo à Ordem dos Advogados do Brasil (OAB) apenas a "atuação supletiva" quando necessária (Moraes e Silva, 1984, p. 94-99). Nesse período, a defesa de um modelo público nacional de assistência judiciária, que atuasse tanto na esfera criminal quanto na cível, começava a se tornar consistente, e um dos principais obstáculos a esse projeto era identificado por seus defensores: a advocacia privada. Tinha início uma campanha, encabeçada principalmente pelos próprios defensores e assistentes judiciários de alguns estados, que visava implantar o projeto da Defensoria Pública no Brasil inteiro. Como resultado, ainda nos anos 1980 começaram a surgir novas instituições de assistência judiciária em certos locais, como em Minas Gerais e no Mato Grosso do Sul ${ }^{18}$, adotando uma estrutura de organização semelhante à do Rio de Janeiro.

O intercâmbio entre defensores e outros servidores públicos que exerciam a assistência judiciária em vários estados levou, em 1984, à formação de uma entidade de classe de âmbito nacional, a Federação Nacional dos Defensores Públicos (Fenadep), atualmente denominada Associação Nacional dos Defensores Públicos (Anadep). Esse é um marco importante, pois o projeto nacional de institucionalização da Defensoria ganhou uma entidade organizada para levá-lo adiante e para defender os interesses dos membros dessa instituição, os quais passavam a se reconhecer como uma categoria única espalhada por todo o país. Na Constituinte de 1987-1988, a Fenadep desempenhou um papel importante, conforme apresentamos adiante. Os defensores públicos perceberam que a Constituinte era uma janela de oportunidade importante para promover o projeto de institucionalização nacional da Defensoria. Membros da Fenadep e de associações estaduais de defensores acompanharam de perto todo o processo constituinte, lutando para incluir a Defensoria no novo texto constitucional e, assim, fixar no plano normativo federal o modelo público de

\footnotetext{
17 Como a assistência judiciária no Rio de Janeiro era incumbência dos defensores públicos desde a década de 1950, outros arranjos para esse serviço não foram implementados no estado e, assim, as demais carreiras de operadores do direito não tiveram a oportunidade de desenvolver interesse maior por esse tipo de serviço. 18 Em entrevista, Suely Pletz Neder, a primeira procuradora-geral da Assistência Judiciária no MS, contou que o contato com defensores fluminenses influenciou a implantação da instituição de assistência jurídica sul-mato-grossense (Neder, entrevista, 2015).
} 
assistência jurídica que se consolidava no Rio de Janeiro e começava a ser implantado em outros estados.

Na próxima seção mostramos que os defensores foram, em grande medida, bemsucedidos nessa empreitada. A Constituição determinou a criação da Defensoria Pública em todos os estados e na União, mas a previsão constitucional encontrou forte resistência de outras categorias de operadores do direito. Uniformizar a assistência jurídica no país com o modelo institucional da Defensoria exigia que vários estados abandonassem ou reduzissem outras formas de execução desse serviço, o que afetava o interesse de atores influentes do sistema de justiça. Esse embate corporativo e institucional está registrado nos debates da Constituinte, a seguir reconstituídos.

\section{Defensoria Pública e acesso à justiça nos debates da Constituinte}

A ANC culminava o processo de redemocratização do país após mais de duas décadas de regime militar. Para atender aos anseios democráticos da época e não ter sua legitimidade questionada, a Constituinte foi organizada em uma estrutura descentralizada de trabalhos e aberta à participação de diversos atores. O resultado foi um texto constitucional longo e que inclui quase todos os aspectos da vida política (Elkins, Ginsburg Melton, 2009, p. 105), contendo algumas "cláusulas absurdamente detalhadas" (Elster, 2008 , p. 21) e constitucionalizando diversos dispositivos que disciplinam políticas públicas, em vez de limitarem-se a temas estruturais da organização do Estado e do jogo político (Arantes e Couto, 2006, 2012). A assistência jurídica às pessoas necessitadas é um exemplo de serviço público que recebeu maior grau de detalhamento no texto constitucional. Os constituintes, além de estabelecerem que o acesso à justiça é um direito fundamental que deve ser garantido pelo Estado, também definiram que a defesa e a orientação jurídica de pessoas carentes devem ser realizadas por uma nova instituição, composta por servidores concursados e com certas características específicas: a Defensoria Pública. A previsão constitucional da instituição foi uma vitória dos defensores. Delegações de defensores e assistentes judiciários acompanharam de perto os trabalhos da ANC e "não se afastaram de Brasília por um só instante" (Neder, 2008, p. 223), atuando junto aos deputados e senadores constituintes para que a Defensoria fosse inserida na nova Constituição, nos termos pretendidos pela categoria. Essa pretensão dos defensores encontrou, contudo, forte resistência de outros operadores do direito e alguns membros da Constituinte.

A ANC foi organizada em Comissões Temáticas dedicadas a discutir matérias específicas para o novo texto constitucional e a apresentar seus anteprojetos à Comissão de Sistematização. Cada Comissão Temática, por sua vez, era dividida em três Subcomissões que deveriam realizar os primeiros debates e elaborar o anteprojeto sobre áreas de responsabilidade da sua respectiva Comissão. A Defensoria, por ser uma instituição destinada a compor o sistema de justiça, foi introduzida no anteprojeto da 
Subcomissão do Poder Judiciário e do Ministério Público, que integrava a Comissão de Organização dos Poderes e Sistema de Governo.

Ao longo do processo constituinte, a Defensoria Pública foi um tema bastante discutido na Subcomissão e na Comissão Temática, e recebeu muitas emendas e destaques para alteração durante as Comissões de Sistematização e de Redação. Desde o início dos trabalhos da ANC, é possível identificar três linhas de objeção relacionadas à inclusão da Defensoria no texto constitucional. A primeira traduz disputas corporativas entre defensores públicos, que queriam institucionalizar a Defensoria como política nacional de acesso à justiça, e outras profissões jurídicas que desempenhavam a assistência judiciária em alguns estados, tais como procuradores estaduais e advogados. Integrantes dessas carreiras jurídicas se posicionaram contra a constitucionalização da Defensoria, ou tentaram construir alternativas que permitiriam a coexistência da nova instituição ao lado da assistência judiciária desempenhada por advogados e/ou procuradores.

A segunda linha de objeção à Defensoria está relacionada à primeira, mas sua origem não é essencialmente motivada por interesses corporativos. Ela expressa a resistência de governos estaduais que utilizavam outras modalidades de prestação da assistência judiciária em aceitar a obrigação constitucional de criar a Defensoria. Tal resistência em alguns momentos configura uma forma de proteger interesses de carreiras jurídicas expressivas dentro do Estado, mas se destaca por defender, principalmente, a autonomia do ente federativo na formulação da sua própria política de assistência jurídica, de acordo com as circunstâncias que Ihe são peculiares. Na visão de políticos oriundos de estados que já possuíam outro modelo de assistência judiciária instaurado, a criação da Defensoria significava adotar uma estrutura mais cara, com uma nova burocracia jurídica, para desempenhar uma política pública que já existia.

Por fim, a terceira linha de objeção surgiu quando a Defensoria procurou equipararse institucionalmente ao Ministério Público, cujos membros foram resistentes à ideia de que uma nova instituição do sistema de justiça pudesse usufruir dos mesmos princípios institucionais, prerrogativas, direitos e garantias conquistados pelo MP ${ }^{19}$. Nessa frente de resistência, alguns promotores e procuradores de justiça eram relutantes em aceitar a existência de outra instituição do sistema de justiça em igualdade com o Ministério Público. Isso poderia significar uma disputa por recursos e/ou funções no futuro.

Essas três objeções podem ser interpretadas como efeitos institucionais ou policy effects, na medida em que a organização do sistema de justiça e a existência de diferentes regimes institucionalizados de uma política pública influenciaram a formação de interesses e a estratégia dos atores com relação à uniformização do serviço de acesso à justiça no Brasil. Os constituintes eleitos por estados onde já havia uma forma incipiente de Defensoria representaram, em regra, os defensores públicos, que formavam nesses locais o principal grupo de interesse em torno do tema da assistência jurídica. Todavia, os

\footnotetext{
19 Para uma análise completa da reformulação institucional do MP, ler Kerche (1999) e Arantes (2002).
} 
constituintes de estados que adotavam outras formas de promover essa política representavam, com maior ênfase, interesses de atores que buscavam manter ou ampliar seu espaço de atuação, em oposição à previsão de uma Defensoria institucionalmente forte. Além disso, a centralidade que o Ministério Público adquiria no sistema de justiça criava outra frente de oposição às pretensões dos defensores.

Desvelar essas três linhas de objeção é essencial para entender o texto final da Constituição sobre a Defensoria Pública. Para facilitar a compreensão, os debates e disputas serão reconstituídos nesta seção seguindo as etapas do processo constituinte, destacando como as três oposições à previsão constitucional da Defensoria - a corporativa, a baseada na autonomia dos estados e a relativa à centralidade institucional no sistema de justiça - estiveram presentes em cada etapa, mostrando quais foram os principais atores envolvidos e quais as consequências desses conflitos para o texto final da Constituição que trata da Defensoria.

\section{Subcomissão do Poder Judiciário e do Ministério Público}

A Subcomissão do Poder Judiciário e do Ministério Público tinha como figura principal o relator, função exercida por Plínio de Arruda Sampaio (PT-SP). Cabia ao relator elaborar um anteprojeto, o qual seria submetido à apreciação dos demais constituintes membros da Subcomissão para apresentarem suas emendas, que poderiam ser aceitas ou rejeitadas pelo relator. Na sequência, o anteprojeto e as emendas seriam votados na Subcomissão, cujo texto aprovado seria encaminhado para a Comissão Temática. Plínio de Arruda, político brasileiro conhecido por seu posicionamento à esquerda no espectro ideológico, foi promotor do estado de São Paulo e durante a ANC atuou em prol do fortalecimento do Ministério Público, tendo sido um dos principais responsáveis pelo novo perfil que a instituição viria a assumir (Arantes, 2002, p. 21).

Já na primeira reunião para eleição da Subcomissão, a questão da Defensoria Pública foi apresentada pelo deputado Sílvio de Andrade Abreu Júnior (PMDB-MG) ${ }^{20}$, advogado mineiro que, quando foi secretário de Justiça em Minas Gerais (1983-1986), apoiou a formação do órgão de Assistência Judiciária desse estado, que era composto por defensores públicos (Oliveira, 2015). Para ele, uma Defensoria "igualada e nivelada" ao MP era necessária para garantir a assistência jurídica aos pobres, razão pela qual propunha inclusive a alteração do nome da Subcomissão para "do Poder Judiciário, do Ministério Público e da Defensoria Pública" (Brasil, 1987a, 1a Reunião, p. 7). Imediatamente, o constituinte Michel Temer (PMDB-SP), que era procurador estadual e havia sido

\footnotetext{
${ }^{20}$ A biografia dos constituintes pode ser consultada no sítio da Câmara dos Deputados, pelo link: <http://www2.camara.leg.br/atividade-legislativa/legislacao/Constituicoes_Brasileiras/constituicaocidada/constituintes/parlamentaresconstituintes/biografia-dos-parlamentares-constituintes>. Acesso em: 6 nov. 2017.
} 
procurador-geral do estado de São Paulo, manifestou-se de forma contrária, deixando clara a oposição corporativa:

(...) apenas me oporia, com a devida vênia, à sugestão do Constituinte Sílvio Abreu, na medida em que esta Constituição deveria também incluir a idéia de Defensoria Pública. Nos Estados, há um grande litígio entre Ministério Público, Defensores Públicos e Procuradores Públicos. No meu Estado, São Paulo, os Procuradores Públicos é que exercitam a atividade da assistência judiciária e dela não querem abrir mão, até porque tomam essa função como de grande relevância no Poder Executivo estadual (Brasil, 1987a, 1a Reunião, p. 7).

Nas reuniões seguintes, constituintes de estados que já haviam implantado um órgão próprio para assistência judiciária fizeram uma campanha para que fosse realizada audiência específica com representantes das associações dos defensores públicos, com o objetivo de apresentar aos constituintes de outros estados, que desconheciam essa instituição, a função e a importância dela. Começava a ficar nítida uma tendência que se manteve nas demais Comissões: constituintes de estados que já possuíam um órgão semelhante à atual Defensoria representaram, em regra, as pretensões dos membros dessa instituição na ANC. Dentro da Subcomissão, destacaram-se nesse papel o já citado Sílvio Abreu (PMDB-MG) e seu par Plínio Martins (PMDB-MS). A insistência deles levou ao agendamento de uma audiência com a participação dos defensores públicos. Na 5 a Reunião Ordinária, compareceram à Subcomissão os defensores Suely Pletz Neder (MS), José Antônio Neves César (MG) e Roberto Vitagliano (RJ), como representantes da Fenadep. 0 discurso deles chamou a atenção para a necessidade social de implantar a Defensoria em todos os estados e na União, visando atender as pessoas sem recursos para custear o acesso à justiça, que, segundo apontavam, compunham $80 \%$ da população brasileira na época. A pretensão era fazer isso pela via constitucional, conforme destacou a então presidente da Fenadep, Suely Neder:

A nossa proposta, portanto, é no sentido de que fique constando do texto constitucional, em capítulo próprio, a institucionalização da assistência judiciária como órgão do Estado, obrigação do Estado, que é atividade, a nível extrajudicial e judicial, na defesa dos direitos dos juridicamente necessitados, inclusive contra o próprio Estado. Que sejam assegurados aos membros da assistência judiciária os direitos, garantias e prerrogativas que são assegurados aos membros dos demais órgãos que integram a administração da Justiça. E que haja uma organização da assistência judiciária a nível nacional, em carreira própria, integrada por cargos providos, inicialmente, em caráter de exclusividade, por concurso público de provas e títulos (Brasil, 1987a, p. 72). 
A aspiração dos defensores era, portanto, criar uma obrigação constitucional determinando aos estados a implantação da Defensoria Pública como uma instituição que fosse: estruturada em carreira própria, com ingresso inicial por meio de concurso público; organizada nacionalmente, com base em princípios institucionais que lhe garantissem unidade, independência e autonomia financeira e administrativa; e cujos membros tivessem asseguradas as mesmas prerrogativas, direitos e garantias dos integrantes do MP. Sem esses atributos, os defensores argumentavam que a defesa jurídica da população carente seria apenas ficta, já que o concurso garantiria o ingresso de pessoas capacitadas e vocacionadas à atividade, ao passo que a autonomia da instituição e a prerrogativa de seus membros assegurariam a independência que a função exige, pois muitas vezes é preciso defender o direito do pobre contra os ricos ou até mesmo contra o próprio Estado (Brasil, 1987a, 5a Reunião Ordinária, p. 62-72)21. Em síntese, o objetivo era alcançar um avanço institucional semelhante ao que estava sendo trilhado pelo Ministério Público. Em diversas passagens de suas intervenções na Subcomissão, os defensores equiparam a importância da sua função à dos promotores/procuradores de justiça: se a estes cumpre proteger os direitos indisponíveis da sociedade, àqueles cabe a defesa dos direitos individuais da população carente, "se bem que sempre do ponto de vista do interesse social" (Brasil, 1987a, 5a Reunião Ordinária, p. 63); se o MP se responsabiliza pela acusação no processo penal, a Defensoria assume a função da defesa. Para equilibrar as partes dentro do processo e garantir a defesa eficiente dos necessitados, era preciso, portanto, igualar as instituições.

A proximidade do deputado Sílvio Abreu com os defensores públicos era patente. Desde o início dos debates, a atuação do constituinte a favor da Defensoria Pública estava em perfeita harmonia com as pretensões dos defensores e, ao longo de toda a ANC, ele defendeu as reivindicações da categoria22. Outros deputados e senadores levantavam, contudo, ressalvas quanto às pretensões dos defensores públicos. Michel Temer apresentou um argumento contrário à constitucionalização da Defensoria, que misturava oposição corporativa e defesa da autonomia dos estados membros. Após afirmar que o valor fundamental em debate é a assistência judiciária, e não a instituição em si que a desempenha, o ex-procurador-geral de São Paulo indagou:

Por que só a Defensoria Pública? Não seria o caso de dizermos que a assistência judiciária, valor fundamental, valor altamente prezável pelos povos, deverá ser prestada, preferencialmente, [pela Defensoria] nos

\footnotetext{
${ }^{21}$ A luta por autonomia institucional era uma pauta antiga dos defensores fluminenses (Rocha, 2004).

22 Além do Silvio Abreu, outros constituintes demonstravam ter proximidade com defensores e suas associações, como Plínio Martins (PMDB/MS), Vivaldo Barbosa (PDT/RJ) e Mário Bouchardt (PMDB/MG). Vivaldo Barbosa afirmou na justificativa da emenda no 3C0282-2 que conhecia de perto a Defensoria Pública. Mário Bouchardet destacou na justificativa da emenda no 3C0546-5 que "o texto foi aprovado pelas delegações das entidades representativas dos defensores públicos".
} 
Estados? Note-se que utilizo a expressão 'preferencialmente pelas defensorias públicas', podendo, entretanto, ser atribuída a outros órgãos da administração, porque creio, Sr. ${ }^{a}$ expositora [Suely Neder], que esta seria uma homenagem ao princípio federativo, ao princípio da autonomia dos Estados. O Estado se organiza e presta a sua administração de acordo com as suas possibilidades. Então, é muito provável que em um Estado a Defensoria Pública seja criada, mas em outro - e aqui trago o exemplo de São Paulo e outros Estados - a Procuradoria do Estado presta esta assistência também com muita eficiência, em que os advogados dativos de alguma maneira prestam um desempenho muito acentuado e profícuo em relação à assistência judiciária, porque - repito - volto a dizer, este é o valor de que o Constituinte está efetivamente homenageando (Brasil, 1987a, 5a Reunião Ordinária, p. 74$5)$.

O relator Plínio de Arruda Sampaio, por sua vez, também não acatou as reivindicações dos defensores tão facilmente. Em um primeiro momento, questionou a conveniência e a necessidade de incluir a Defensoria na Constituição, alegando que não seria um assunto tipicamente constitucional:

Então, a Constituição estabelece aquelas garantias que são fundamentais para o exercício da democracia. Mas, por exemplo, não há na Constituição um capítulo que disponha sobre o médico sanitarista, sobre o engenheiro de obras dos ministérios; sobre os geólogos, que são, também, profissões extremamente importantes.

O que se garante na Constituição àquelas profissões que são muito sujeitas à pressão, muito sujeitas às injunções, muito sujeitas a fatores externos que obstaculizam o seu pleno exercício (Brasil, 1987a, 5a Reunião Ordinária, p. 71).

O relator também indagou a relevância de uniformizar a assistência jurídica, já que em alguns estados a atribuição estava a cargo dos procuradores estaduais, de repartições específicas ou de advogados dativos nomeados para defender os necessitados. Contudo, ao longo dos trabalhos da Subcomissão, seu posicionamento muda parcialmente "depois de muita conversa com Silvio Abreu e Plínio Martins, os mais árduos defensores da Defensoria Pública nesta Subcomissão", segundo suas próprias palavras (Brasil, 1987a, 9a Reunião Extraordinária, p. 237) ${ }^{23}$. Plínio incluiu em seu anteprojeto um dispositivo que atendia parte das pretensões da Fenadep ${ }^{24}$, mas não equiparou a Defensoria ao MP. Para

\footnotetext{
23 Nas atas dos debates constituintes não está claro por que Plínio de Arruda mudou seu posicionamento. Aparentemente, a atuação de alguns constituintes e dos próprios defensores foi o fator determinante, pois conseguiram o apoio da maioria dos membros da Subcomissão, conforme mostramos a seguir.

${ }^{24}$ A proposta do relator organizava a Defensoria em carreira com ingresso por concurso público, garantia a inamovibilidade, com a ressalva de que não era absoluta como a do promotor e a do juiz, e a independência funcional aos seus membros.
} 
ele, embora já estivesse presente em alguns estados, a instituição era ainda uma novidade e, como tal, não deveria "ter uma estratificação constitucional demasiadamente ampla, difícil depois de ser modificada na prática do exercício de suas funções" (Brasil, 1987a, 9a Reunião Extraordinária, p. 196). Entretanto, o principal ponto da argumentação do relator revela a oposição institucional à criação de uma instituição equiparada ao Ministério Público:

Estamos aqui fazendo uma nova Nação, na medida em que a estamos reconstruindo. É preciso, então, que se contenha o ímpeto, com certa ponderação, com certo equilíbrio. Estamos criando uma instituição que é uma novidade, constituindo enorme transformação no nosso arcabouço constitucional, o Ministério Público. Foi um passo que dei não sem muita meditação. Criamos um organismo que, a rigor, não depende de poder algum, que quebra uma multissecular forma de organização do Estado. É uma evolução que tem sua base teórica, que foi discutida e numa série de congressos, de aportes jurídicos e de publicações.

Ora, se criarmos outra igual estaremos exagerando. É importante instituirmos a carreira do defensor público, mas não podemos esquecer que há uma hierarquia de funções. Por mais legítimo que seja o interesse de um indivíduo pobre que litiga com outro, ele não tem, na sociedade, a mesma importância que uma ofensa a uma lei criminal, um conflito entre poderes, uma violação de direitos individuais, uma violação de direitos difusos, que estamos dando a instituições constitucionalmente ultraprotegidas, para que possam exercer com independência a função contra o poder, contra a prepotência.

Não vejo que o advogado dos mais necessitados tenha esta categoria. É importante que o serviço seja resguardado. Não veria nenhum inconveniente em que os Estados, de acordo com seus orçamentos e suas colocações, pagassem ao defensor público o mesmo salário que recebe o promotor. Mas estabelecer isto como obrigação constitucional, e com esta abrangência, tenho a impressão de que é avançar um pouco a teoria e a experiência. (Brasil, 1987a, 9a Reunião Extraordinária, p. 239. Grifos deste artigo).

Apesar da oposição do relator, a Subcomissão aprovou ${ }^{25}$ a emenda no 4 de autoria do constituinte Silvio Abreu, que reconheceu à Defensoria os mesmos princípios institucionais do MP e estendeu aos defensores as garantias, prerrogativas e direitos dos promotores. Os defensores públicos viam, assim, todas as suas pretensões serem atendidas no anteprojeto da Subcomissão. Essa conquista provisória dos defensores

\footnotetext{
25 Mesmo Michel Temer, até então contrário à constitucionalização da Defensoria, votou pela aprovação da emenda no 4. Interessante notar que, na etapa seguinte, ele passou a defender a paridade de vencimentos entre membros das PGE e do MP, e usou como argumento o fato de ter sido aprovada a paridade entre os vencimentos dos magistrados, promotores e defensores. Paralelamente, ele propôs à Comissão Temática uma emenda que enfraquecia a Defensoria Pública.
} 
contou com a participação decisiva dos constituintes eleitos por estados que na época já possuíam a Defensoria Pública instituída ${ }^{26}$ e enfrentou objeção mais forte por parte dos constituintes eleitos em estados onde havia outra forma de assistência judiciária.

Observa-se, assim, que nesse debate a filiação partidária teve menos importância do que o estado de origem do constituinte. Além disso, já é possível identificar nessa etapa as três linhas de objeção à previsão constitucional de uma Defensoria institucionalmente forte. Michel Temer misturou defesa corporativa com argumento da autonomia dos estados contra a uniformização da assistência jurídica, enquanto Plínio de Arruda expressou a oposição institucional à criação de uma nova instituição equiparada ao MP. A Tabela 1 sintetiza os temas reivindicados pelos defensores ou por seus representantes na Subcomissão e aqueles que foram aprovados nessa fase da $\mathrm{ANC}^{27}$ :

Tabela 1

A Defensoria Pública na subcomissão

\begin{tabular}{|l|c|c|}
\hline Temas & $\begin{array}{c}\text { Reivindicação dos } \\
\text { defensores nessa fase }\end{array}$ & $\begin{array}{c}\text { Aprovado na } \\
\text { subcomissão }\end{array}$ \\
\hline $\begin{array}{l}\text { Carreira própria com ingresso } \\
\text { inicial por concurso público }\end{array}$ & $\sqrt{ }$ & $\sqrt{ }$ \\
\hline Princípios institucionais do MP28 & $\sqrt{ }$ \\
\hline $\begin{array}{l}\text { Direitos, garantias e prerrogativas } \\
\text { dos membros do MP }\end{array}$ & $\sqrt{ }$ & $\sqrt{ }$ \\
\hline $\begin{array}{l}\text { Vedações profissionais previstas } \\
\text { aos membros do MP29 }\end{array}$ & & $\sqrt{ }$ \\
\hline
\end{tabular}

Fonte: Anais da Assembleia Constituinte.

\footnotetext{
26 O bloco que apoiou as pretensões dos defensores na Subcomissão contou com a participação dos seguintes constituintes: Silvio Abreu (PMDB-MG), Plínio Martins (PMDB-MS), Adolfo Oliveira (PL-RJ), Ronaro Corrêa (PFL-MG), Mário Bouchardet (PMDB-MG) e Vivaldo Barbosa (PDT-RJ). Todos vinham de estados que já tinham um órgão de assistência judiciária específico, a Defensoria da época.

$27 \mathrm{Na}$ Tabela 1, o sinal de visto indica que a medida foi reivindicada pelos defensores e/ou aprovada pela Subcomissão. A célula vazia significa que, embora a questão tenha sido aprovada, não foi possível observar manifestação dos defensores e seus representantes sobre esse tema. O intuito da Tabela 1 e das seguintes é apenas registrar quais temas foram inseridos e/ou removidos do dispositivo sobre a Defensoria conforme o processo constituinte avançou.

28 Os princípios institucionais eram unidade, indivisibilidade, independência funcional e autonomia administrativa.

29 Após a aprovação da emenda no 4, a Subcomissão ainda decidiu, por iniciativa do constituinte Jairo Carneiro (PFL-BA), impor aos defensores as mesmas vedações profissionais aplicadas aos membros do MP e reconhecer os mesmos vencimentos. Entretanto, no texto final do anteprojeto da Subcomissão, foi incluída apenas referência às vedações, sem tratar dos vencimentos.
} 
Comissão da Organização dos Poderes e Sistema de Governo

$\mathrm{Na}$ etapa seguinte da ANC, os defensores perderam parte das conquistas obtidas na Subcomissão. A Comissão Temática foi basicamente composta de duas fases. Inicialmente, seus membros apresentaram emendas aos anteprojetos elaborados pelas Subcomissões, as quais eram aceitas ou rejeitadas pelo relator incumbido de apresentar um anteprojeto substitutivo. Na segunda fase, eram feitas emendas ao texto do relator, que agora emitia parecer contrário ou favorável a elas para, na sequência, serem submetidas à votação. Novamente a função do relator era central, e foi desempenhada na Comissão pelo deputado Egídio Ferreira Lima (PMDB-PE).

Entre as emendas apresentadas ao anteprojeto da Subcomissão, destaca-se a oposição corporativa à constitucionalização da Defensoria Pública. Das dez emendas sobre o tema, cinco eram contrárias à Defensoria por considerarem que outras carreiras jurídicas poderiam realizar a mesma função. Nelton Friedrich (PMDB-PR), por exemplo, apresentou duas emendas que visavam diminuir a importância da Defensoria Pública. Na emenda no 301149-6, ele propunha reduzir o texto constitucional sobre a Defensoria, deixando apenas a previsão de que a sua função era defender os juridicamente necessitados. A outra emenda de sua autoria queria incluir um novo artigo que garantisse às pessoas carentes a livre escolha do assistente jurídico, que deveria ser remunerado pelo Estado quando não integrasse o serviço público ${ }^{30}$. A justificativa dessas duas emendas revela o interesse de outro ator, a $O A B$, pois o constituinte afirmou que "[é] importante acrescentar que esta Proposta de Emenda é recomendada pela Ordem dos Advogados do Brasil" (Brasil, 1987b, p. 321). Michel Temer mais uma vez atuou como representante dos procuradores de São Paulo e solicitou a inclusão de um novo dispositivo sobre assistência jurídica, permitindo que os estados e o Distrito Federal atribuíssem esse serviço a suas respectivas Procuradorias $^{31}$. Em sua argumentação, Temer dizia:

Não há dúvida de que é dever inarredável do Estado possibilitar aos necessitados o acesso gratuito e eficiente à Justiça.

Se esse serviço deve ser cometido a um órgão específico, como, por exemplo, uma Defensoria Pública, ou às Procuradorias de Estado é matéria que pertine ao particular interesse do Estado membro que, dentro de suas peculiaridades, deve equacionar e definir a questão.

A experiência de muitos Estados (como por exemplo São Paulo, Alagoas, Rio Grande do Sul, etc.) tem demonstrado a perfeita harmonia no desempenho pelas Procuradorias Gerais das funções típicas de advogado do Estado e do cidadão pobre (Brasil, 1987b, p. 383) 32 .

\footnotetext{
30 Emenda no 301150-0.

31 Emenda no 301428-2.

32 Nessa fase, Além de Nelton Friedrich e Michel Temer, Benedito Monteiro (PMDB-PA), que foi promotor de justiça no Pará, propôs que o MP exercesse a defesa dos necessitados (emenda no 300782-1), ao passo que
} 
Do lado dos que advogavam a favor da Defensoria, a principal emenda foi apresentada pelo deputado Fábio Raunheitti (PTB-RJ)33. O texto proposto era mais modesto do que a previsão do anteprojeto da Subcomissão, pois não estabelecia os mesmos princípios institucionais e garantias do Ministério Público. Procurava incluir, contudo, a figura de um procurador-geral como chefe da Defensoria Federal e conceder expressamente a vitaliciedade (que já fazia parte das prerrogativas conquistadas na Subcomissão) aos defensores. Nas justificativas, o deputado expressa sua ligação com os membros da instituição: "[e]ste projeto foi elaborado por um grupo de Defensores Públicos do Estado do Rio de Janeiro" (Brasil, 1987b, p. 25)34. Essa proposta dos defensores do Rio de Janeiro foi a única emenda sobre a Defensoria Pública parcialmente aprovada pelo relator Egídio Ferreira Lima, que acatou apenas a supressão que a emenda trazia em relação ao anteprojeto da Subcomissão, retirando do texto os princípios institucionais. Por sua própria iniciativa, ele ainda retirou a previsão de concurso público para ingresso na carreira, alterou o caput do dispositivo para uma redação mais sintética e deixou de determinar que lei complementar federal estabeleceria normas gerais para a Defensoria dos estados. Em um único golpe, o anteprojeto do relator suprimiu boa parte das reivindicações que os defensores consideravam necessárias para a consolidação de uma instituição forte o suficiente para defender os pobres com eficiência. Após essa alteração, Sílvio Abreu buscou, sem êxito, alterar o anteprojeto do relator para conferir novamente à Defensoria Pública os mesmos princípios institucionais do Ministério Público ${ }^{35}$. Ele conseguiu apenas reintroduzir a previsão de que lei complementar federal iria estabelecer normas gerais para a organização da Defensoria nos estados ${ }^{36}$, uma conquista importante porque vinculava a prestação da assistência jurídica nos estados ao modelo institucional definido para a Defensoria Pública no plano federal.

No entanto, as emendas ao anteprojeto do relator eram em sua maioria contrárias à pretensão dos defensores públicos. Dentre as 19 emendas sobre a Defensoria, 7, a maioria formulada por constituintes paulistas ${ }^{37}$, pretendiam conferir também às Procuradorias estaduais a possibilidade de prestar assistência jurídica. As justificativas afirmavam que muitos estados já contavam com os serviços de sua PGE para garantir a

Jutahy Magalhães Júnior (PMDB-BA) sugeria que, enquanto não houvesse Defensoria, suas funções fossem assumidas por advogados dativos (emenda no 300892-4).

33 Emenda no 300103-2.

34 O fato de os defensores terem apresentado uma emenda que reduzia as conquistas obtidas na Subcomissão sugere uma ação estratégica. Quando perceberam que não conseguiriam aprovar todas as reivindicações da categoria, foi preciso restringir a demanda àquilo que consideravam mais importante e negociar o que era viável, conforme relatou Suely Pletz Neder (entrevista, 2015).

35 Emenda no 3S0985-1.

36 Emenda no 3S0988-5. Carlos Sant'Anna (PMDB-BA) propôs outra emenda (n 3S0715-7) aprovada em favor da Defensoria. Com ela, defensores passariam a ter os mesmos vencimentos dos membros do MP.

${ }^{37}$ Apresentaram emendas procurando atribuir a assistência jurídica também às PGEs os constituintes Antônio Salim Curiati (PDS-SP), José Carlos Grecco (PMDB-SP), Maurício Nasse (PMDB-PR), Hélio Manhães (PMDBES), Nion Albernaz (PMDB-GO) e Michel Temer (PMDB-SP). Nos estados desses constituintes, a assistência judiciária era exercida pela Procuradoria. Interessante notar que SP só criou a Defensoria em 2006, GO, em 2012 e PR, em 2013 (Moreira, 2016). 
assistência jurídica e que, até que a Defensoria fosse implantada de fato nesses locais, era imprescindível que os procuradores continuassem exercendo tal função. Nenhuma dessas emendas foi aprovada 38 .

Na Comissão Temática o interesse corporativo e o argumento da autonomia dos estados $^{39}$ foram os dois principais eixos de objeção à previsão constitucional da Defensoria Pública nos termos almejados pelos seus membros. Embora não se verifique a oposição institucional de membros do MP nessa etapa, a supressão dos princípios institucionais foi a maior derrota sofrida pelos defensores até então. A Tabela 2 resume os temas que os defensores, ou os constituintes que os representavam, tentaram manter no texto do anteprojeto e aqueles que foram suprimidos pela comissão. Na Tabela 2, o sinal " $\sqrt{ }$ " significa que o tema foi reivindicado pela categoria e/ou mantido no texto aprovado, ao passo que $O$ " $X$ " indica que a comissão suprimiu o item do anteprojeto:

Tabela 2

A Defensoria Pública na Comissão Temática

\begin{tabular}{|l|c|c|}
\hline Temas & $\begin{array}{c}\text { Reivindicado nessa } \\
\text { fase }\end{array}$ & $\begin{array}{c}\text { Aprovado na } \\
\text { comissão }\end{array}$ \\
\hline $\begin{array}{l}\text { Carreira própria com ingresso } \\
\text { inicial por concurso público }\end{array}$ & $\sqrt{ }$ \\
\hline Princípios institucionais do MP & & $\mathrm{X}$ \\
\hline $\begin{array}{l}\text { Direitos, garantias e prerrogativas } \\
\text { do MP }\end{array}$ & & $\sqrt{ }$ \\
\hline $\begin{array}{l}\text { Equiparação de vencimentos com } \\
\text { Judiciário e MP }\end{array}$ & & $\sqrt{ }$ \\
\hline $\begin{array}{l}\text { Vedações profissionais previstas } \\
\text { para os membros do MP }\end{array}$ & $\sqrt{ }$ \\
\hline $\begin{array}{l}\text { Lei complementar para organizar } \\
\text { DPEs }\end{array}$ & $\sqrt{ }$ \\
\hline $\begin{array}{l}\text { Procurador-Geral da Defensoria } \\
\text { Pública }\end{array}$ & $\sqrt{ }$ \\
\hline
\end{tabular}

Fonte: Anais da Assembleia Constituinte.

\section{Comissão de Sistematização, Plenário e Comissão de Redação}

Seguindo o processo constituinte, na Comissão de Sistematização o projeto passou por tramitação semelhante à adotada nas fases anteriores: inicialmente foram apresentadas emendas, incluídas ou não no substitutivo do relator, o qual seria submetido a outra rodada de emendas para elaboração de um segundo substitutivo, sujeito a novas

\footnotetext{
38 Michel Temer se destacou novamente como representante dos procuradores. Ao mesmo tempo em que procurou assegurar aos procuradores a assistência judiciária, defendeu a equiparação dos vencimentos dessa categoria com as demais carreiras jurídicas, utilizando como argumento o fato de a equiparação salarial ter sido concedida aos defensores (emenda no 3S0976-1).

39 Além de Michel Temer, que defendeu a autonomia dos estados para definir o modo como iriam prestar assistência judiciária, o deputado José Lourenço (PFL-BA) pretendia criar a Defensoria apenas na União (emenda no 3S0007-1), sem vincular os estados.
} 
propostas de alteração. A relatoria na Comissão de Sistematização foi exercida pelo deputado Bernardo Cabral (PMDB-AM).

Nas primeiras rodadas de emendas, chama atenção a quantidade de propostas que pretendiam suprimir o parágrafo que assegurava aos defensores as garantias, direitos, prerrogativas e vedações atribuídas pela Constituição aos membros do MP40. Outras duas emendas tinham um perfil corporativo ${ }^{41}$, enquanto a proposta de Gerson Peres (PDS-PA) suprimia a Defensoria do texto constitucional ${ }^{42}$ e Oswaldo Lima Filho (PMDB-PE) pretendia organizar a instituição nos estados exclusivamente por lei estadual, visando afirmar a autonomia das unidades federativas ${ }^{43}$.

Do lado dos representantes dos defensores públicos, atuaram nesse momento: Flávio Raunheitti (PTB-RJ), que defendia uma proposta elaborada por defensores fluminenses para incluir concurso público, vitaliciedade e a figura do Defensor PúblicoGeral como chefe da instituição oriundo da própria carreira; Wilson Martins (PMDB-MS), propondo incluir novamente os princípios institucionais do MP e mudar a redação para prever que aos defensores seria assegurado o mesmo regime jurídico dos membros da promotoria; e Nelson Carneiro (PMDB-RJ), cuja emenda defendia concurso público para ingresso na carreira e a criação da figura do Defensor-Geral ${ }^{44}$.

A pressão para eliminar o artigo que equiparava os defensores aos membros do MP parece ter surtido efeito, tendo em vista que, no primeiro projeto substitutivo apresentado pelo relator, o parágrafo que continha tal previsão foi suprimido. Por essa razão, na etapa seguinte foram apresentadas 31 emendas solicitando que fosse aplicado o mesmo regime jurídico do Ministério Público aos defensores ${ }^{45}$. Os representantes dos defensores públicos também propunham outras demandas da categoria, como os princípios institucionais, o concurso público para ingresso na carreira e a criação da figura do

\footnotetext{
40 Apresentaram emendas para vedar a equiparação de defensores e promotores: Moema São Thiago (PDT/$\mathrm{CE})$, Edison Lobão (PFL-MA), Anna Maria Rattes (PMDB-RJ), Caio Pompeu (PMDB-SP), Antônio Carlos Mendes Thame (PFL-SP), Theodoro Mendes (PMDB-SP), Lúcio Alcântara (PFL-CE), Firmo de Castro (PMDB-CE), Arnaldo Rosa Prato (PMDB-MG), Paulo Roberto Cunha (PDC-GO), Chico Humberto (PDT-MG), Roberto Balestra (PDC-GO) e José Richa (PMDB-PR).

41 A emenda no 1P09299-0 apresentada por Jutahy Magalhães (PMDB-BA) autorizava o exercício da assistência jurídica por advogados dativos enquanto não houvesse Defensoria em todas as comarcas, e a emenda no 1P11991-0, de José Ignácio Ferreira (PMDB-ES), estabelecia a prestação da assistência jurídica, onde não houvesse Defensoria, aos procuradores estaduais.

42 Emenda no 1P18934-9.

43 Emenda no 1P14605-4.

${ }^{44}$ As emendas citadas nesse parágrafo são, respectivamente: no 1P00483-7, no 1P05673-0 e no 1P191921.

${ }^{45}$ Apresentaram proposta de equiparação do regime jurídico: Feres Nader (PDT-RJ), José Elias (PTB-MS), Siqueira Campos (PDC-GO), Nelson Carneiro (PMDB-RJ), Jamil Haddad (PSB-RJ), Sotero Cunha (PDC-RJ), Márcio Braga (PMDB-RJ), Plínio Martins (PMDB-MS), Cunha Bueno (PDS-SP), Osmar Leitão (PFL-RJ), José Carlos Coutinho (PL-RJ), Furtado Leite (PFL-CE), Joaci Gós (PMDB-BA), Lélio Souza (PMDB-RS), Adroaldo Streck (PDT-RS), Ivo Cersósimo (PMDB-MS), Víctor Faccioni (PDS/RS), Sílvio Abreu (PMDB-MG), Egídio Ferreira Lima (PMDB-PE), Edmilson Valentim (PCdoB-RJ), Anna Maria Rattes (PMDB-RJ), Mário Lima (PMDB$B A)$, Carlos Chiarelli (PFL-RJ), Saulo Queiróz (PFL-RJ), José Dutra (PMDB-AM), Vivaldo Barbosa (PDT-RJ), Adolfo Oliveira (PL-RJ) e Fernando Henrique Cardoso (PMDB-SP).
} 
Defensor Público-Geral ${ }^{46}$. No parecer das emendas, nota-se que o relator era favorável à adoção do regime jurídico do Ministério Público, mas contrário à concessão dos princípios institucionais do MP à Defensoria, o que se confirmou no segundo projeto substitutivo, que incluiu apenas a previsão que assegurava aos defensores, quando em dedicação exclusiva, o mesmo regime jurídico do MP. A Tabela 3 apresenta os temas discutidos na Comissão de Sistematização, novamente marcando com " $\sqrt{ }$ " as questões demandadas pelos representantes dos defensores públicos e/ou aprovadas pela Comissão, e com " $X$ " os tópicos que foram retirados do anteprojeto nessa etapa do processo constituinte. Os espaços vazios indicam que o tema não foi reivindicado ou não foi incluído e/ou alterado pela Comissão.

Tabela 3

A Defensoria Pública na Comissão de Sistematização

\begin{tabular}{|l|c|c|}
\hline Temas & $\begin{array}{c}\text { Reivindicado } \\
\text { nessa fase }\end{array}$ & $\begin{array}{c}\text { Aprovado na } \\
\text { comissão }\end{array}$ \\
\hline $\begin{array}{l}\text { Carreira própria com ingresso inicial } \\
\text { por concurso público }\end{array}$ & $\sqrt{ }$ & $\sqrt{ }$ \\
\hline Princípios institucionais do MP47 & $\sqrt{ }$ \\
\hline $\begin{array}{l}\text { Direitos, garantias e prerrogativas } \\
\text { dos membros do MP }\end{array}$ & $\begin{array}{c}\text { Somente a } \\
\text { vitaliciedade }\end{array}$ & $\mathrm{X}$ \\
\hline $\begin{array}{l}\text { Equiparação de vencimentos com } \\
\text { Judiciário e MP }\end{array}$ & $\sqrt{ }$ \\
\hline $\begin{array}{l}\text { Vedações profissionais previstas para } \\
\text { os membros do MP }\end{array}$ & $\sqrt{ }$ \\
\hline $\begin{array}{l}\text { Lei complementar para organizar } \\
\text { DPEs }\end{array}$ & $\sqrt{ }$ \\
\hline Prever o Defensor Público-Geral ${ }^{48}$ & $\sqrt{ }$ \\
\hline Regime jurídico do MP & & $\begin{array}{c}\text { Somente em caso de } \\
\text { dedicação exclusiva }\end{array}$ \\
\hline
\end{tabular}

Fonte: Anais da Assembleia Constituinte.

Com o projeto já em discussão no Plenário da ANC, o deputado Gerson Peres (PDSPA) investiu contra a Defensoria ${ }^{49}$, com o objetivo de suprimi-la do texto constitucional, pelos motivos que ele já havia exposto na Comissão de Sistematização:

(...) julgar que ela [Defensoria Pública] é mais um conjunto burocrático a ser incrustado no sistema de governo, por achar que é mais um processo muito oneroso para o País, e por achar que é mais um conjunto que vai se articular dentro das procuradorias em busca de vinculações salariais. (...). Eu

\footnotetext{
46 A previsão de chefe administrativo oriundo da carreira e eleito por seus pares, algo que havia sido implantado na Defensoria fluminense em 1987, era percebida como importante para afirmar a autonomia da instituição.

47 Os princípios institucionais do MP já haviam sido excluídos na Comissão Temática.

48 Durante a ANC, propostas que visavam criar o chefe da Defensoria Pública ora chamavam essa figura de "Procurador-Geral da Defensoria Pública", ora se referiam a ela como "Defensor Público-Geral".

49 Emenda no 2P01627-8.
} 
perguntaria a V. Ex. ${ }^{a}$ [Nelson Carneiro - PMDB-RJ], não seria mais simples criar a Defensoria Pública dentro da Procuradoria-Geral do País e integrar esses defensores no quadro dessa Procuradoria, sem que se estabeleça um órgão autônomo que venha criar mais problemas para a já tão burocrática e tão difícil administração deste País? (Brasil, 1988a, 26a Reunião Extraordinária da Comissão de Sistematização, p. 608).

Ao argumento do constituinte paraense se aliou o deputado José Fogaça (PMDBRS), alegando que a assistência jurídica não dependia da previsão constitucional da Defensoria, pois os estados poderiam adotar o modelo do Rio Grande do Sul, onde havia um departamento administrativo ligado à Procuradoria responsável por essa função, ou criar "serviço de assistência gratuita, em que advogados remunerados pelo Estado cumprem o mesmo papel do Defensor Público" (Brasil, 1988a, 26a Reunião Extraordinária, 609). O modelo dos advogados particulares e a atuação da PGE foram levantados novamente como formas alternativas à criação da Defensoria. Nesse momento, Nelson Carneiro (PMDB-RJ) defendeu a manutenção da Defensoria Pública no texto constitucional, apontando que a grande vantagem dela seria garantir estabilidade e independência para que o profissional do direito pudesse atuar efetivamente a favor do jurisdicionado necessitado ${ }^{50}$.

Outra proposta contrária à Defensoria partiu do deputado José Costa (PMDB-AL), que propôs suprimir do projeto a previsão de que seria assegurado aos integrantes da Defensoria, quando em dedicação exclusiva, o regime jurídico do Ministério Público ${ }^{51}$. Sua justificava alegava que o defensor público atua em nome da parte (pessoa necessitada), enquanto o MP atua em nome dos interesses da sociedade, e, sendo assim, não faria sentido atribuir a um advogado o mesmo regime jurídico do representante da sociedade, tampouco diferenciar o defensor público dos demais advogados ${ }^{52}$. Sua proposta recebeu parecer favorável do relator Bernardo Cabral (PMDB-AM), para quem "as razões aduzidas eram convincentes" 53 .

Nesse momento, Silvio Abreu agiu mais uma vez em defesa da Defensoria Pública, apresentando emenda que visava fortalecer a instituição ${ }^{54}$. Em primeiro lugar, propunha a alteração do caput do dispositivo que iria prever a Defensoria, para destacar que se tratava

\footnotetext{
50 Esse era um dos principais argumentos utilizado há tempos pelos defensores, sobretudo os fluminenses, para defender a autonomia da instituição. Segundo a emenda no 1P19192-1, apresentada por Nelson Carneiro, para que a Defensoria fosse efetiva seria preciso incluir na Constituição a previsão de concurso público para ingresso na carreira, instituir a figura do procurador-geral da Defensoria Pública como chefe da instituição e equiparar seus membros aos integrantes do MP.

51 Emenda no 2P00126-2.

52 Nessa emenda, José Costa também argumentava que a expressão "o mesmo regime jurídico" não poderia significar igualdade de vencimentos, pois o projeto de Constituição proibia a equiparação de qualquer natureza, para o efeito de remuneração de pessoal do serviço público (Brasil, 1988b, p. 51-52). Trata-se da previsão do atual inciso XIII do artigo 37 da Constituição.

$53 \mathrm{O}$ parecer sobre emendas pode ser consultado pelo link:

<http://www.senado.gov.br/legislacao/BasesHist/>. Acesso em: 6 nov. 2017.

54 Emenda no 2P01066-1.
} 
de uma instituição "permanente e essencial à função jurisdicional do Estado", bem como que o acesso à justiça era um direito fundamental na nova Constituição. Essa proposta também incluía a figura do procurador-geral da Defensoria Pública, nomeado pelo presidente da República para chefiar a instituição, e assegurava expressamente aos defensores "os mesmos direitos, garantias e prerrogativas dos membros do Ministério Público", aplicando-se ainda as mesmas vedações.

Nessa disputa entre a proposta de José Costa para excluir a previsão que conferia o mesmo regime jurídico do Ministério Público aos defensores, de um lado, e a emenda de Sílvio Abreu para deixar evidente a equiparação entre defensores públicos e os membros do MP, de outro, atingiu-se um meio termo. Com o apoio do relator Bernardo Cabral, a expressão "mesmo regime jurídico" foi suprimida do projeto, mas, atendendo em parte às reivindicações dos defensores, o texto sofreu as seguintes alterações: o caput do dispositivo da Defensoria passou a prever expressamente que se tratava de uma instituição "essencial à função jurisdicional do Estado"55 e que o acesso à justiça estava previsto entre os direitos fundamentais; incluiu o concurso público para o ingresso na carreira; e assegurou aos defensores apenas uma garantia atribuída aos membros do MP, a inamovibilidade, impedindo-os, ainda, de exercer a "advocacia fora das atribuições institucionais". Os princípios institucionais e a equiparação aos membros do Ministério Público estavam definitivamente excluídos do texto da Constituição que seria promulgado no dia 5 de outubro de 1988. Consolidavam-se, nesse momento, as conquistas parciais dos defensores na ANC, pois o artigo destinado à Defensoria não sofreria mudanças na sequência do processo constituinte. A Tabela 4 expõe os temas reivindicados pelos representantes dos defensores públicos na etapa do Plenário, bem como as questões aprovadas ou rejeitadas no anteprojeto dessa fase:

\footnotetext{
55 A proposta de Sílvio Abreu dizia que a Defensoria é instituição "permanente e essencial". A palavra "permanente" não foi incluída no texto original da Constituição, só sendo inserida com a EC 80/2014.
} 
Tabela 4

A Defensoria Pública no plenário

\begin{tabular}{|c|c|c|}
\hline Temas & $\begin{array}{l}\text { Reivindicado } \\
\text { nessa fase }\end{array}$ & Aprovado no plenário \\
\hline $\begin{array}{l}\text { Carreira própria com ingresso inicial } \\
\text { por concurso público }\end{array}$ & $\sqrt{ }$ & $\sqrt{ }$ \\
\hline $\begin{array}{l}\text { Direitos, garantias e prerrogativas dos } \\
\text { membros do MP }\end{array}$ & $\sqrt{ }$ & Somente a inamovibilidade \\
\hline $\begin{array}{l}\text { Vedações profissionais previstas para } \\
\text { os membros do MP }\end{array}$ & $\sqrt{ }$ & $\begin{array}{c}\text { Só proíbe advocacia fora } \\
\text { da Defensoria }\end{array}$ \\
\hline Procurador-Geral da Defensoria & $\sqrt{ }$ & \\
\hline Regime jurídico do MP & & $\mathrm{x}$ \\
\hline $\begin{array}{l}\text { Redação: "instituição permanente e } \\
\text { essencial" }\end{array}$ & $\sqrt{ }$ & $\begin{array}{c}\text { Só inclui "instituição } \\
\text { essencial" }\end{array}$ \\
\hline $\begin{array}{l}\text { Redação: dizer que o acesso à justiça } \\
\text { é um direito fundamental }\end{array}$ & $\sqrt{ }$ & $\begin{array}{l}\text { Referência ao art. 50, } \\
\text { LXXIV, da Constituição }\end{array}$ \\
\hline
\end{tabular}

Fonte: Anais da Assembleia Constituinte.

Em entrevista, Suely Pletz Neder explicou que o relator Bernardo Cabral informou a ela e a outros representantes dos defensores que o texto constitucional dedicaria apenas um artigo e um parágrafo à Defensoria. Suely relatou ainda que os defensores não conseguiriam de forma alguma conquistar, naquela época, as três garantias atribuídas à magistratura e aos membros do MP, quais sejam: vitaliciedade, irredutibilidade de vencimentos e inamovibilidade. Era preciso optar por apenas uma. Eles acabaram escolhendo e conseguindo aprovar a inamovibilidade (Neder, entrevista, 2015) ${ }^{56}$. O acordo obtido para incluir a Defensoria na Constituição nesses termos é confirmado pelas votações nominais no Plenário da ANC. A instituição foi inserida no texto constitucional em uma votação ampla, que aprovou em bloco todo o capítulo referente às "funções essenciais à justiça", por 357 votos favoráveis e 55 contrários (Brasil, 1988a, 242a Sessão, p. 322) ${ }^{57}$.

$\mathrm{Na}$ sequência da ANC, somente duas emendas sobre a Defensoria foram apresentadas e ambas rejeitadas, confirmando que um consenso havia sido obtido. Uma delas propunha suprimir o trecho que previa a organização das Defensorias em cargos de carreira com ingresso por concurso público ${ }^{58}$. Segundo a argumentação do autor, o deputado Antônio Carlos Konder Reis (PDS-SC), a criação de um órgão de carreira pública seria gastar com burocracia supérflua em detrimento da universalização do atendimento, uma vez que o serviço de assistência judiciária poderia ser desempenhado por intermédio da OAB e custeado pelo estado, como ocorria em Santa Catarina desde $1979^{59}$. Suprimir

\footnotetext{
56 Vitaliciedade e irredutibilidade já estavam asseguradas para todos os servidores públicos concursados. A inamovibilidade seria o que faltava para garantir a independência funcional dos defensores.

57 Três sessões depois, o Plenário aprovou mudança no texto acrescentando o concurso público para ingresso na carreira, a inamovibilidade e a vedação da advocacia fora da instituição. Tal alteração foi aprovada por 330 votos favoráveis e apenas 2 contrários (Brasil, 1988a, 245a Sessão, p. 432).

58 Emenda no 2T01194-6.

${ }^{59}$ Konder Reis foi o governador de Santa Catarina (1975-1979) que instituiu tal modelo dativo de assistência judiciária no estado.
} 
o texto indicado na emenda, de acordo com o constituinte, seria imperioso para "permitir que os estados cumpram seu dever constitucional de atender aos necessitados, na forma mais indicada por suas peculiaridades" (Brasil, 1988c, 146, grifos deste artigo). Era mais uma tentativa de afirmar a autonomia dos estados na definição do modelo de assistência jurídica que iriam adotar. Na Comissão de Redação, etapa destinada apenas a ajustes redacionais no texto do projeto, novamente o deputado Konder Reis fez a última investida contra a obrigação de instituir a Defensoria Pública nos estados. Na emenda ${ }^{60}$, ele sugeriu inverter a ordem da redação do parágrafo único do artigo sobre a Defensoria, mudança que eximiria os estados de constituírem a Defensoria com base em cargos de carreira com ingresso inicial por concurso ${ }^{61}$. Ao defender a proposta, Konder Reis alegou que:

A alteração não prejudica o sentido da proposição, cujo objetivo é não impor aos Estados um modelo rígido para Defensoria Pública. A procedência da proposta é tanto mais evidente quanto o projeto dá competência aos Estados para legislar sobre Defensoria Pública e Assistência Jurídica. Altero apenas a colocação da expressão "e prescreverá normas gerais" para organização nos Estados, no final. (...). O que a Constituição não pode fazer é manter uma contradição. Se damos atribuição, competência aos Estados para legislar sobre Defensoria Pública e Assistência Jurídica, não se pode engessar no art. 134 essa competência dos Estados. Devo ainda dizer à Comissão que, concretamente, existem inúmeros Estados que podem e devem organizar sua Defensoria Pública sem obedecer a esse modelo que a Constituição prevê acertadamente - para o plano federal e para a Defensoria Pública dos Territórios e do Distrito Federal (Brasil, 1988a, 8a Reunião Ordinária, p. 190, grifos deste artigo).

Diante da objeção do constituinte Bonifácio de Andrada (PDS-MG) - seu correligionário de um estado que já havia instituído a carreira de defensor público - de que a mudança proposta daria aos estados condição de criar a Defensoria Pública sem concurso público, o autor da emenda justificou:

Jamais iria propor que a Defensoria Pública dos Estados fosse organizada em carreira sem a exigência do concurso. Ocorre, porém, Sr. Presidente [Ulysses Guimarães], que há Estados, como o de Santa Catarina, que têm uma

\footnotetext{
60 Emenda PR00374-2.

61 A mudança proposta buscava alterar o parágrafo único de "Lei complementar organizará a Defensoria Pública da União e do Distrito Federal e dos Territórios e prescreverá normas gerais para sua organização nos Estados, em cargos de carreira, providos, na classe inicial, mediante concurso público de provas e títulos, assegurada a seus integrantes a garantia da inamovibilidade e vedado o exercício da advocacia fora das atribuições institucionais" para "Lei complementar organizará a Defensoria Pública da União e do Distrito Federal e dos Territórios em cargos de carreira, providos, na classe inicial, mediante concurso público de provas e títulos, assegurada a seus integrantes a garantia da inamovibilidade e vedado o exercício da advocacia fora das atribuições institucionais, e prescreverá normas gerais para sua organização nos Estados" (grifos do artigo para destacar a diferença sutil entre as duas versões).
} 
Defensoria Pública modelar e que não obedece a esse modelo de cargo e carreira. Estou aqui com o projeto de lei e quero dar liberdade aos Estados. Se eles organizarem a carreira, farão concurso. Mas poderão organizar a Defensoria Pública sem criar a carreira (Brasil, 1988a, 8a Reunião Ordinária, p. 191, grifos deste artigo).

Novamente a autonomia dos estados surgia como objeção à determinação constitucional de criar a Defensoria. Após a manifestação do relator Bernardo Cabral contrária à proposta de alteração, a emenda foi rejeitada e o texto final sobre a Defensoria continuou prevendo a criação em todo o país de um modelo de assistência jurídica formado por servidores públicos concursados. Além do artigo 134 da Constituição, o Ato das Disposições Constitucionais Transitórias (ADCT) dedicou o artigo 22 à Defensoria 62 , para fixar uma regra de transição assegurando aos servidores, concursados ou não, que exerciam a função de assistência judiciária antes de 1988 a opção pelo ingresso na nova carreira de defensor. Em entrevista, o defensor público do Rio Grande do Sul, Carlos Guazzelli, disse que esse dispositivo foi uma reivindicação de servidores que exerciam a assistência judiciária, defendiam o projeto de construção da Defensoria e pretendiam migrar para essa nova instituição. Para a aprovação desse artigo, relatou, pesou a influência dos defensores de Minas Gerais e de alguns assistentes judiciários do Rio Grande do Sul, que não eram concursados na época (Guazzelli, entrevista, 2015). Esse evento retrata a atuação de servidores de outros órgãos estaduais destinados à assistência judiciária, diferentes da Defensoria, durante a ANC.

\section{Resultado constituinte: projeto de consolidação da Defensoria permaneceu aberto}

Os debates transcritos demonstram que os defensores públicos perceberam a Constituinte como uma janela de oportunidade para fortalecer a instituição que integravam e para expandi-la para todo o país, como o modelo de assistência jurídica obrigatório. Eles atuaram, principalmente por meio de suas associações de classe, como um grupo de interesse ao longo de todo o processo constituinte, com o objetivo de incluir a obrigação constitucional de criar a Defensoria Pública na União, no Distrito Federal e em todos os estados, com os mesmos princípios institucionais, direitos e prerrogativas do MP. Assim, da mesma maneira que membros do Ministério Público estiveram presentes na Constituinte para defender a aprovação de seu projeto institucional (Kerche, 1999; Arantes, 2002; Maciel e Koerner, 2014), defensores públicos e assistentes judiciários pressionaram para obter a previsão constitucional da Defensoria em termos semelhantes ao modelo que estava sendo traçado para o MP. A presença ativa dos defensores e dos seus

62 "Art. 22. É assegurado aos defensores públicos investidos na função até a data de instalação da Assembléia Nacional Constituinte o direito de opção pela carreira, com a observância das garantias e vedações previstas no art. 134, parágrafo único, da Constituição". 
representantes constituintes na ANC foi essencial para direcionar o debate sobre a assistência jurídica. Uma vez incluída no anteprojeto da Subcomissão, a Defensoria esteve presente nos textos elaborados por todas as Comissões seguintes, e o debate mais importante a partir daí não seria prever ou não a criação da Defensoria Pública na Constituição, mas definir se era necessário uniformizar, por via constitucional, quais seriam as suas características institucionais, as prerrogativas dos seus integrantes e a autonomia dos estados para implantá-la conforme a sua conveniência. Em outras palavras, a previsão constitucional da Defensoria Pública não foi uma iniciativa que partiu da maioria dos constituintes, tampouco um consenso da ANC sobre a necessidade de uniformizar a assistência jurídica para promover a justiça social, mas sim uma demanda de certas carreiras jurídicas que exerciam a assistência judiciária, a qual foi canalizada no processo constituinte e teve que enfrentar forte resistência.

Do outro lado da disputa, constituintes eleitos por estados que desenvolveram formas distintas de prestar assistência judiciária se opuseram à previsão constitucional de uma Defensoria Pública institucionalmente forte e vinculante para todo o país. As três formas de objeção à imposição constitucional da Defensoria foram identificadas ao longo dos debates. A principal oposição corporativa partiu dos procuradores estaduais, principalmente os paulistas, representados por Michel Temer, que exerciam a assistência judiciária em alguns estados. Também há indícios de que seccionais estaduais da OAB tinham interesses opostos à construção de uma instituição pública nacional responsável pela assistência jurídica. Isso porque, na época, alguns estados haviam adotado o arranjo de assistência baseado em advogados particulares remunerados pelos cofres públicos. Procuradores estaduais e advogados não queriam abrir mão dessa função e por isso é possível observar a resistência deles à previsão constitucional da Defensoria. A segunda linha de objeção partia do argumento da autonomia dos estados membros, que não queriam ficar vinculados a uma forma mais onerosa de garantir aos necessitados o acesso à justiça. Nos locais onde o modelo de advogados particulares era utilizado ou a PGE assumia também o serviço de assistência judiciária, a criação da Defensoria era vista por muitos atores políticos como um gasto desnecessário. Simultaneamente, havia também a oposição institucional dos membros do Ministério Público, a terceira linha de objeção, que em boa parte da ANC foi erigida pelo deputado Plínio de Arruda Sampaio, então membro do MP paulista.

Essas três formas de oposição são efeitos institucionais da organização do sistema de justiça até 1988. Como não havia uniformidade legal sobre o serviço de assistência judiciária, cada estado adotava uma forma de desempenhá-lo. Isso criou, como policy effects, a objeção de certas categorias de profissões jurídicas e dos próprios governos estaduais à adoção do modelo estruturado com base na Defensoria Pública. Ademais, a força e a centralidade do Ministério Público, conquistadas por seus membros em um longo processo de reformulação institucional (Kerche, 1999; Arantes, 2002), formavam outro efeito oposto à construção de uma nova instituição do sistema de justiça que almejava se 
equiparar ao MP. Em muitos processos judiciais, essas instituições estariam necessariamente em lados opostos e, em outras ocasiões, poderiam disputar a legitimidade para representar interesses da sociedade perante o Judiciário.

Em torno dessas três linhas de conflito, carreiras jurídicas e seus representantes constitucionais atuaram na ANC. A redação do dispositivo sobre a Defensoria Pública no texto original da Constituição é o produto dessas disputas. Enquanto os defensores alegavam que só uma instituição pública organizada nacionalmente com autonomia e prerrogativas funcionais poderia garantir efetivamente o acesso à justiça, opunham-se a essa pretensão, com diversas propostas e argumentos, procuradores estaduais, advogados, promotores de justiça e políticos que defendiam a autonomia dos estados na formulação do serviço de assistência judiciária. Como resultado, o artigo 134 da Constituição atendeu parcialmente às demandas dos defensores públicos: previu para estados, Distrito Federal e União a criação da Defensoria a partir de normas gerais comuns, organizada em cargos de carreira com ingresso inicial por concurso público. A oposição de outros atores, contudo, impediu a almejada equiparação ao MP e deixou a redação constitucional aberta para que os estados adiassem a criação de suas Defensorias e definissem o grau de autonomia que concederiam a elas.

Essa previsão constitucional postergou a consolidação institucional pretendida pelos defensores e transportou a luta deles para uma batalha travada em duas frentes. A atuação para conferir autonomia à Defensoria e garantias aos seus integrantes continuaria no plano do legislativo federal, mas a batalha para expandir a instituição precisava ser enfrentada também nas arenas estaduais. Em ambas as frentes, oposições de outras carreiras jurídicas seriam novamente uma forte barreira ao projeto de consolidação da Defensoria (Moreira, 2016). Portanto, os conflitos presentes na ANC são centrais para entender o processo de institucionalização da Defensoria que se seguiu, nas décadas seguintes, à promulgação do texto constitucional. Boa parte dos embates presentes na Constituinte foram reproduzidos novamente quando os defensores buscaram conquistar novas funções e autonomias e instalar a instituição em todos os estados do país.

Observa-se nesses embates da Constituinte o ativismo político de atores estatais, ou seja, que categorias profissionais oriundas da administração pública estiveram presentes na ANC para fortalecer suas instituições e carreiras. Semelhante à importância de promotores e procuradores de justiça na reformulação institucional do MP (Kerche, 1999; Arantes, 2002), defensores e assistentes judiciários desempenharam papel central no processo de construção da Defensoria. Eles formularam e propagaram o projeto que visava uniformizar, por meio da Constituição, o serviço de assistência jurídica de todo o país a partir de uma instituição específica.

Sobre a transformação institucional do MP, a literatura diverge quanto aos fatores preponderantes para a sua aprovação na ANC. Ao tratar da Constituinte, o trabalho de Arantes (2002) destacou o voluntarismo político e o lobby exercido pelos membros do Ministério Público, enquanto Kerche ressaltou que o lobby em si não foi suficiente, pois o 
sucesso dos integrantes do MP estaria em oferecer um projeto de instituição que se adequava ao ambiente da Constituinte e às perspectivas democráticas dominantes naquele momento, o que tornava tal projeto "bastante 'vendável'" para os deputados e senadores da ANC (1999, p. 134). Dessa maneira, o Ministério Público aprovado pela Constituinte não estaria em contradição com o texto constitucional, mas, ao contrário, seria coerente com aspectos centrais que guiaram a ANC. Uma terceira linha de explicação foi apresentada por Maciel e Koerner (2014), que ampliam o processo histórico para situar os membros do MP durante a redemocratização, enfatizando as alianças com movimentos sociais e atores políticos que foram constituindo ao longo do tempo. O capital político, social e simbólico acumulado pelo MP nesse período o fortaleceu, associando o seu projeto a outras mobilizações e pautas democráticas do período, o que facilitou no momento de "angariar decisões políticas favoráveis a realização da sua pauta" (2014, p. 114).

A história da Defensoria Pública na ANC revela intensa atuação dos defensores e de outras carreiras de assistência judiciária. Assim como os membros do MP, os defensores perceberam que a Constituinte era uma importante janela de oportunidade para aprovarem seu projeto institucional. O lobby, portanto, também fez parte da sua estratégia de atuação. No entanto, os defensores encontraram mais dificuldades do que promotores e procuradores de justiça, e conseguiram aprovar um dispositivo constitucional para a Defensoria que era consideravelmente mais modesto do que aquele estabelecido para o MP. Ao que tudo indica, não foi a incapacidade de apresentar uma pauta em sintonia com os objetivos da Constituinte a razão da maior dificuldade dos defensores públicos. $\mathrm{Na}$ verdade, eles argumentaram ao longo de toda a ANC que somente uma Defensoria Pública estabelecida nacionalmente nos termos do Ministério Público seria capaz de promover os direitos previstos na Constituição para $80 \%$ da população brasileira, que estimavam ser a parcela do povo sem recursos para arcar com os custos da advocacia privada (Brasil, 1987a, 5a Reunião Ordinária, p. 73).

Parece ter influenciado negativamente no caso dos defensores públicos o fato de ainda não serem parte, naquela época, de uma carreira uniforme, articulada e presente em todo o território nacional, como já era o MP. Conforme vimos, os defensores começaram a se organizar nacionalmente nos anos 1980. Nesse período, os membros do Ministério Público já possuíam um associativismo e um projeto institucional mais sólidos, inclusive com vitórias legislativas importantes, como a Lei de Ações Civis Públicas em 1985 (Kerche, 1999; Arantes, 2002), e com alianças com movimentos e atores políticos que se alinhavam no processo de redemocratização (Maciel e Koerner, 2014). Não obstante, é ainda mais relevante para explicar a dificuldade enfrentada pelos defensores a forte oposição que as três linhas de objeção descritas neste artigo representaram ao seu projeto institucional. A Defensoria Pública precisava construir seu espaço no sistema de justiça e isso despertava a resistência de outros atores, incluindo certas carreiras jurídicas, como procuradores estatais e membros do MP. Tais conflitos foram determinantes para aprovação do artigo sobre a Defensoria na Constituição. Constata-se, assim, que mudanças 
importantes no sistema de justiça brasileiro devem ser analisadas levando em conta os interesses e a atuação política de atores que o integram (Arantes, 2015; Arantes e Moreira, 2016). Tais atores, comprometidos com projetos que visam fortalecer sua instituição e a política pública que exercem, agem politicamente para atingir seus objetivos.

Essa constatação e os embates observados na ANC são contribuições relevantes para as reflexões da literatura existente sobre Defensoria Pública. O potencial da instituição para promover a transformação social do país, normalmente enfatizado pela literatura, precisa ser devidamente analisado levando em consideração as dificuldades para inserção da Defensoria no sistema de justiça, bem como os interesses corporativos dos seus integrantes, que são atores centrais no processo de formação e fortalecimento da instituição, cujos interesses corporativos muitas vezes guiam a Defensoria Pública por caminhos distintos daqueles esperados pela literatura. A análise do processo de construção institucional da Defensoria, que tem na Constituinte um capítulo central, representa um passo decisivo para avaliar a instituição e adequar as expectativas sobre a sua atuação.

Thiago de Miranda Queiroz Moreira - Universidade de São Paulo, Departamento de Ciência Política, Ringgold Standard Institution, Programa de Pós-Graduação em Ciência Política. E-mail: <thiago.moreira@usp.br>.

\section{Referências bibliográficas}

Arantes, R. B. Ministério Público e política no Brasil. São Paulo: Idesp/Sumaré: Educ., 2002.

"Rendición de cuentas y pluralismo estatal en Brasil: Ministerio Público y Policía Federal". In: Desacatos 49, Ciudad de México, p. 28-47, set.-dez., 2015.

ARAntes, R.; Couto, C. "Constituição, governo e democracia no Brasil". Revista Brasileira de Ciências Sociais, São Paulo, vol. 21, nº 61, p. 41-62, 2006.

. "Constitutionalizing policy: the Brazilian Constitution of 1988 and its impact on governance". In: NolTE, D.; SCHILling-VACAFLOR, A. (orgs.). New constitutionalism in Latin America: promises and practices. Vol. 1. New York: Ashgate, p. 203- 222, 2012.

ARANTES, R.; Moreira, T. "Defensoria Pública e acesso à justiça no novo CPC". In: Didier JR., F.; SousA, J. A. (org.). Defensoria Pública. Coleção Repercussões do Novo CPC, vol. 5, 2016.

BRASIL. "Atas da Assembleia Nacional Constituinte". Diário da Assembleia Nacional Constituinte, 1987a. Disponível em: <http://www2.camara.leg.br/>. Acesso em: 23 jan. 2017.

. "Emendas oferecidas à III Comissão da Organização dos Poderes e Sistema de Governo". Diário da Assembleia Nacional Constituinte, 1987b. Disponível em: <http://www2.camara.leg.br/> . Acesso em: 23 jan. 2017. 
Brasil. "Atas da Assembleia Nacional Constituinte". Diário da Assembleia Nacional Constituinte, 1988a. Disponível em: <http://www2.camara.leg.br/>. Acesso em: 23 jan. 2017.

. "Projeto de Constituição (A): Emendas oferecidas em plenário". Vol. I. Diário da Assembleia Nacional Constituinte, 1988b. Disponível em: <http://www2.camara.leg.br/>. Acesso em: 23 jan. 2017.

. "Projeto de Constituição (B): Emendas oferecidas em plenário". Diário da Assembleia Nacional Constituinte, 1988c. Disponível em: <http://www2.camara.leg.br/>. Acesso em: 23 jan. 2017.

Cappelletti, M.; Garth, B. Acesso à justiça. Porto Alegre: Fabris, 1988.

Castro, A. Prefácio. In: Rocha, J. L. Uma história da Defensoria Pública do Estado do Rio de Janeiro e da Associação dos Defensores Públicos do Estado do Rio de Janeiro - ADPERJ. Rio de Janeiro: Lumen Juris, 2004.

CUNHA, L. G. Acesso à justiça e assistência jurídica em São Paulo. In: SADEK, M. T. (org.). Acesso à justiça. São Paulo: Fundação Konrad Adenaeur, 2001.

Cunha, L. G.; Feferbaum, M. Repensando o papel da Defensoria Pública: uma nova estratégia para o aprimoramento da cidadania. In: RÉ, A. I. M. R.; REIS, G. A. S. (orgs.). Temas aprofundados Defensoria Pública. Vol. 2. Salvador: Editora JusPODIVM, p. 17-21, 2014.

Elkins, Z.; Ginsburg, T.; Melton, J. The endurance of national Constitutions. New York: Cambridge University Press, 2009.

ELSTER, J. "The optimal design of a Constituent Assembly". Manuscrito, 2008. Disponível em: <http://www.law.uchicago.edu/audio/by/title/jon_elster_the_optimal_design_of_a_constituent_asse mbly>. Acesso em: 23 jan. 2017.

Guazzelli, C. F. B. Entrevista para: T. M. Q. Moreira. Porto Alegre. 1 arquivo .mp3 (96 min.), 2015.

HACKER, J.; PIERSON, P. "Business power and social policy: employers and the formation of the American Welfare State". Politics \& Society, vol. 30, n², p. 277-325, 2002.

HADDAD, E. (org.). A Defensoria Pública do Estado de São Paulo: por um acesso democrático à justiça. São Paulo: Letras Jurídicas, 2011.

KeRChe, F. "O Ministério Público e a Constituinte de 1987/88". In: SADEK, M. T. (org.). O sistema de justiça. São Paulo: Ed. Sumaré/Fund. Ford, p. 106-137, 1999.

MACIEL, D. A.; KoERner, A. "O processo de reconstrução do Ministério Público na transição política (1974-1985)". Revista Debates, vol. 8, n³, p. 97-117, 2014.

MADeirA, L. "A Defensoria Pública no Brasil: implementação, funcionamento e efetividade do acesso à justiça". In: Anais do $8^{\circ}$ Encontro da Associação Brasileira de Ciência Política (ABCP). Gramado, 2012.

MARCACINI, A. T. R. Assistência jurídica, assistência judiciária e justiça gratuita. Rio de Janeiro: Forense, 1996.

Marona, M. Defensorias Públicas. In: Avritzer, L., et al. (orgs.). Dimensões políticas da justiça. Rio de Janeiro: Civilização Brasileira, p. 352-368, 2013. 
Moraes, H. P.; Silva, J. F. T. Assistência judiciária: sua gênese, sua história e a função protetiva do Estado. $2^{a}$ ed. Rio de Janeiro: Liber Juris, 1984.

Moreira, T. M. Q. "A criação da Defensoria Pública nos estados: conflitos corporativos e institucionais no processo de uniformização do acesso à justiça". 298 f. Dissertação de Mestrado em Ciência Política. Universidade de São Paulo, São Paulo, 2016.

Neder, S. P. Defensoria Pública, criação da Constituição de 1988. In: Ensaios sobre impactos da Constituição Federal de 1988 na sociedade brasileira. Brasília: Edições Câmara, Série Coleções Especiais - Obras comemorativas, no 2, p. 221-233, 2008.

. Entrevistador: T. M. Q. Moreira. Brasília. 1 arquivo .mp3 (60 min.), 2015. A ser disponibilizada em: <http://www.cis.org.br/>.

Oliveira, C. A. A. Defensoria Pública do Estado de Minas Gerais: Raízes. In: Silva, G. S.; Coutinho, A. (orgs.). Memorial da Defensoria Pública brasileira. Brasília: Anadep, p. 23-32, 2015.

Pierson, P. Public policies as institutions. In: Skowronek, S.; Galvin, D.; Shapiro, I. (eds.). Rethinking political institutions: the art of the State. New York: New York University Press, p. 114$130,2006$.

PIERSON, P.; SKOCPOL, T. Historical institutionalism in contemporary political science. In: KATZNELSON, I.; Milner, H. (eds.). Political science: state of the discipline. New York: W.W. Norton, p. 693-721, 2002.

RochA, A. L. A exclusão legal da população carente. Brasília: Thesaurus, 2009.

Rocha, J. L. Uma história da Defensoria Pública do Estado do Rio de Janeiro e da Associação dos Defensores Públicos do Estado do Rio de Janeiro - ADPERJ. Rio de Janeiro: Lumen Juris, 2004.

SADEK, M. T. Efetividade de direitos e acesso à justiça. In: BotTini, P.; RenAult, S. R. T. (coords.). Reforma do Judiciário. São Paulo: Saraiva, 2005.

. A Defensoria Pública no sistema de justiça brasileiro. São Paulo: Apadep em Notícias, p. 2-6, 30 jul., 2008. Disponível em:

<http://adepes.com.br/Arquivo/Documents/PUB/4_3_2013_artigo_sadek.pdf>. Acesso em: 21 nov. 2017.

SAntos, B. S. Para uma revolução democrática da justiça. 3a ed. São Paulo: Cortez, 2011.

Thelen, K.; Steinmo, S. Historical institutionalism in comparative politics. In: Steinmo, S.; TheLEN, K.; LONGSTRETH, F. (eds.). Structuring politics: historical institutionalism. New York: Cambridge University Press, p. 1-32, 1992.

ZAFFALON, L. Uma fenda na justiça: as inovações democráticas construídas na Defensoria Pública. São Paulo: Hucitec, 2010. 


\section{Anexo}

\section{Defensoria Pública nos anteprojetos e projetos da ANC}

Anteprojeto da Subcomissão do Poder Judiciário e do Ministério Público

Art. 47 - A Defensoria Pública, Instituição permanente e essencial à função jurisdicional do Estado, tem como incumbência a postulação e a defesa, em todas as instâncias, dos juridicamente necessitados, podendo atuar, ainda, judicial ou extrajudicialmente, contra pessoas físicas e jurídicas de direito público ou privado.

Parágrafo único - São princípios institucionais da Defensoria Pública a unidade, a indivisibilidade e a independência funcional, gozando, ainda, de autonomia administrativa. Art. 48 - A Defensoria Pública é organizada, por lei complementar, em carreira composta de cargos de categoria correspondente aos órgãos de atuação do Poder Judiciário.

Parágrafo único - Dar-se-á o ingresso na carreira da classe inicial, mediante concurso público de provas e títulos, não podendo os nomeados, após dois anos de exercício, ser demitidos senão por sentença judiciária ou em virtude de processo administrativo em que Ihes faculte ampla defesa, nem removidos a não ser mediante representação do Procurador-Geral da Defensoria Pública, com fundamento em conveniência de serviço.

Art. 49 - A Defensoria Pública é dirigida pelo Procurador-Geral da Defensoria Pública nomeado pelo Presidente da República, dentre os ocupantes dos cargos da classe final da carreira.

Art. 50 - Ao Defensor Público, como garantia do exercício pleno e da independência de suas funções, são devidas as garantias, prerrogativas e direitos dos membros do Ministério Público, aplicando-se-lhes as mesmas vedações.

Art. 51 - Lei complementar organizará a Defensoria Pública da União em todas as instâncias e estabelecerá normas gerais a serem adotadas na organização da Defensoria Pública dos Estados, do Distrito Federal e dos Territórios, observado o disposto neste Capítulo.

Anteprojeto Substitutivo do Relator da Comissão Temática

Art. 108. É instituída a Defensoria Pública para a defesa, em todas as instâncias, dos juridicamente necessitados.
$\S 1^{\circ}$. Ao Defensor Público são asseguradas as garantias, direitos, prerrogativas e vedações conferidas, por esta Constituição, aos membros do Ministério Público.

$\S 2^{\circ}$. Lei complementar organizará a Defensoria Pública da União em todas as instâncias.

Anteprojeto da Comissão da Organização dos Poderes e Sistema de Governo

Art. 139. É instituída a Defensoria Pública para a defesa, em todas as instâncias, dos juridicamente necessitados.

$\S 1^{\circ}$. Ao Defensor Público são asseguradas as garantias, direitos, vencimentos, prerrogativas e vedações conferidas, por esta Constituição, aos membros do Ministério Público.

$\S 2^{\circ}$. Lei complementar organizará a Defensoria Pública da União, do Distrito Federal e dos Territórios e estabelecerá normas gerais para a organização da Defensoria Pública dos Estados.

Primeiro Projeto Substitutivo do Relator Comissão de Sistematização

Art. 177. É instituída a Defensoria Pública para a orientação jurídica e a defesa, em todos os graus, dos necessitados.

Parágrafo único. Lei complementar organizará a Defensoria Pública da União, do Distrito Federal e dos Territórios e estabelecerá normas gerais para a organização da Defensoria Pública dos Estados.

Segundo Projeto Substitutivo do Relator Comissão de Sistematização

Art. 148. É instituída a Defensoria Pública para a orientação jurídica e a defesa, em todos os graus, dos necessitados.

Parágrafo único. Lei complementar organizará a Defensoria Pública da União, do Distrito Federal e dos Territórios e estabelecerá normas gerais para a organização da Defensoria Pública dos Estados, assegurado o mesmo regime jurídico do Ministério Público, quando em dedicação exclusiva.

Projeto A - Plenário 10 Turno

Art. 155. É instituída a Defensoria Pública para a orientação jurídica e a defesa, em todos os graus, dos necessitados.

Parágrafo único. Lei complementar organizará a Defensoria Pública da União, do Distrito Federal e dos Territórios e estabelecerá 
normas gerais para a organização da Defensoria Pública dos Estados, assegurado aos seus integrantes, quando em dedicação exclusiva, o regime jurídico do Ministério Público.

Projeto B - Plenário 20 Turno

Art. 139. A Defensoria Pública é instituição essencial à função jurisdicional do Estado, incumbindo-lhe a orientação jurídica e a defesa, em todos os graus, dos necessitados, na forma do art. 50, LXXVI.

Parágrafo único. Lei complementar organizará a Defensoria Pública da União e do Distrito Federal e dos Territórios e prescreverá normas gerais para sua organização nos Estados, em cargos de carreira, providos, na classe inicial, mediante concurso público de provas e títulos, assegurada a seus integrantes a garantia da inamovibilidade e vedado o exercício da advocacia fora das atribuições institucionais. Texto Promulgado na Constituição Art. 134. A Defensoria Pública é instituição essencial à função jurisdicional do Estado, incumbindo-lhe a orientação jurídica e a defesa, em todos os graus, dos necessitados, na forma do art. 50, LXXIV.

Parágrafo único. Lei complementar organizará a Defensoria Pública da União e do Distrito Federal e dos Territórios e prescreverá normas gerais para sua organização nos Estados, em cargos de carreira, providos, na classe inicial, mediante concurso público de provas e títulos, assegurada a seus integrantes a garantia da inamovibilidade e vedado o exercício da advocacia fora das atribuições institucionais.

\title{
Resumo
}

A constitucionalização da Defensoria Pública: disputas por espaço no sistema de justiça

A Constituição de 1988 inseriu a Defensoria Pública no sistema de justiça para prestar assistência jurídica às pessoas carentes. Na época, a instituição era uma novidade na maior parte do país e em vários lugares funcionavam outros arranjos de assistência judiciária. Este artigo analisa os debates da Assembleia Constituinte para identificar padrões de conflito entre diferentes atores em torno da constitucionalização da Defensoria. Os debates revelam três linhas de objeção à uniformização da assistência jurídica por meio da Defensoria, as quais são efeitos institucionais dos arranjos estaduais anteriores e da centralidade que o Ministério Público adquiria no sistema de justiça. Observa-se que instituições e políticas públicas, ao influenciarem objetivos e estratégias dos atores, exercem impacto sobre processo de construção/mudança institucional. Esses achados contribuem para a literatura sobre Defensoria Pública, que costuma destacar o potencial da instituição para promoção da justiça social e da democratização da justiça no Brasil, mas tem observado sua incapacidade de efetivar esse potencial na prática, sem identificar, contudo, que isso decorre, em grande medida, da dificuldade de inserção da Defensoria em um sistema de justiça existente.

Palavras-chave: Defensoria Pública; Assembleia Constituinte; conflitos institucionais; ativismo político; atores estatais

\begin{abstract}
The constitutionalization of the Public Defender's Office: disputes over space in the justice system

The 1988 Constitution inserted the Public Defender's Office in the Brazilian justice system in order to provide legal aid to people in need. At this time, the institution was a novelty in many parts of the country, and other institutional arrangements for legal aid were available in various places. This paper has analyzed the Constituent Assembly's debate to identify patterns of conflict concerning the constitutional provision of a Public Defender's Office. The debates reveal three avenues of objection to the standardization of legal aid through the Public Defender's Office, which are institutional effects from previous state arrangements and from the centrality that the Public Prosecutor's Office was acquiring in the justice system. We observe that institutions and public policy, by influencing actors' aims and strategies, affect processes of institutional development and change. These findings contribute to the literature on Public Defense, which stresses the institution's potential to promote social justice and the democratization of the justice system in Brazil. In spite of observing the
\end{abstract}


institution's incapacity to live up to its potential in practice, it isn't able identify that this limitation is, largely, a consequence of the difficulty of inserting a Public Defender's Office into an existing justice system.

Keywords: Public Defender's Office; Constituent Assembly; institutional conflicts; political activism; state actors

\section{Resumen}

\section{La constitucionalización de la Defensoría Pública: disputas por espacio en el sistema de justicia}

La Constitución de 1988 insertó la Defensoría Pública en el sistema de justicia para prestar asistencia jurídica a las personas necesitadas. En la época, la institución era una novedad en la mayor parte del país y en varios lugares funcionaban otros modelos de asistencia judicial. Este trabajo analizó los debates de la Asamblea Constituyente para identificar patrones de conflicto entre diferentes actores en relación con la constitucionalización de la Defensoría. Los debates revelan tres líneas de objeción a la estandarización de la asistencia jurídica a través de la Defensoría, las cuales son efectos institucionales de los modelos estatales anteriores y de la centralidad que el Ministerio Público adquiere en el sistema de justicia. Se observa que instituciones y políticas públicas, al influenciar objetivos y estrategias de los actores, ejercen impacto en el proceso de construcción/cambio institucional. Estos hallazgos contribuyen a la literatura sobre Defensoría Pública, que suele destacar el potencial de la institución para promover la justicia social y la democratización de la justicia en Brasil, pero se ha observado su incapacidad de hacer efectivo este potencial en la práctica, sin identificar que esto deriva, en gran medida, de la dificultad de inserción de la Defensoría en un sistema de justicia existente.

Palabras clave: Defensoría Pública; Asamblea Constituyente; conflictos institucionales; activismo político; actores estatales

\section{Résumé}

La constitutionnalisation de la Défense Publique: les disputes pour l'espace dans le système judiciaire

La Constitution de 1988 a inséré la Défense Publique dans le système judiciaire pour fournir une assistance juridique aux nécessiteux. À l'époque, l'institution était une nouveauté dans la majeure partie du pays et dans plusieurs endroits d'autres régimes d'aide juridique étaient en place. Cette étude a analysé les débats de l'Assemblée constituante pour identifier des modèles de conflit entre les différents acteurs à propos de la constitutionnalisation de la Défense. Les débats révèlent trois lignes d'opposition à la normalisation de l'assistance juridique par la Défense, celles-ci sont les effets institutionnels des dispositions étatiques précédentes et de la centralité que le Ministère Publique acquérait dans le système de justice. On observe que les institutions et les politiques publiques, qui influent sur les objectifs et les stratégies des acteurs, ont un impact sur le processus de construction/changement institutionnel. Ces résultats contribuent à la littérature sur la Défense Publique, qui met souvent en évidence le potentiel de l'institution de promouvoir la justice sociale et la démocratisation de la justice au Brésil, mais qui a constaté son incapacité à réaliser ce potentiel effectivement, sans toutefois identifier que cela découle, dans une large mesure, de la difficulté d'insérer la Défense Publique dans un système de justice existant.

Mots-clés: Défense Publique; Assemblée Constituante; conflits institutionnels; activisme politique; acteurs d'état

Artigo submetido à publicação em 23 de janeiro de 2017. Versão final aprovada em 16 de outubro de 2017. 